\title{
Web-based Tsunami Early Warning System: a case study of the 2010 Kepulaunan Mentawai Earthquake and Tsunami
}

\author{
E. Ulutas ${ }^{1}$, A. Inan ${ }^{2,3}$, and A. Annunziato ${ }^{3}$ \\ ${ }^{1}$ Kocaeli University, Engineering Faculty, Department of Geophysical Engineering, Kocaeli, Turkey \\ ${ }^{2}$ Gazi University, Technology Faculty, Department of Civil Engineering, Ankara, Turkey \\ ${ }^{3}$ European Commission Joint Research Center Institute for the Protection and Citizen, Ispra (VA), Italy \\ Correspondence to: E. Ulutas (ergin@kocaeli.edu.tr)
}

Received: 6 July 2011 - Revised: 25 January 2012 - Accepted: 26 January 2012 - Published: 12 June 2012

\begin{abstract}
This study analyzes the response of the Global Disasters Alerts and Coordination System (GDACS) in relation to a case study: the Kepulaunan Mentawai earthquake and related tsunami, which occurred on 25 October 2010. The GDACS, developed by the European Commission Joint Research Center, combines existing web-based disaster information management systems with the aim to alert the international community in case of major disasters. The tsunami simulation system is an integral part of the GDACS. In more detail, the study aims to assess the tsunami hazard on the Mentawai and Sumatra coasts: the tsunami heights and arrival times have been estimated employing three propagation models based on the long wave theory. The analysis was performed in three stages: (1) pre-calculated simulations by using the tsunami scenario database for that region, used by the GDACS system to estimate the alert level; (2) near-realtime simulated tsunami forecasts, automatically performed by the GDACS system whenever a new earthquake is detected by the seismological data providers; and (3) post-event tsunami calculations using GCMT (Global Centroid Moment Tensor) fault mechanism solutions proposed by US Geological Survey (USGS) for this event. The GDACS system estimates the alert level based on the first type of calculations and on that basis sends alert messages to its users; the second type of calculations is available within $30-40 \mathrm{~min}$ after the notification of the event but does not change the estimated alert level. The third type of calculations is performed to improve the initial estimations and to have a better understanding of the extent of the possible damage. The automatic alert level for the earthquake was given between Green and Orange Alert, which, in the logic of GDACS, means no need or moderate need of international humani-
\end{abstract}

tarian assistance; however, the earthquake generated 3 to $9 \mathrm{~m}$ tsunami run-up along southwestern coasts of the Pagai Islands where 431 people died. The post-event calculations indicated medium-high humanitarian impacts.

\section{Introduction}

Natural hazards such as earthquakes, tsunamis, land subsidence, coastal inundations, floods, volcanic eruptions and landslides threaten Indonesia because it is in the collision zone of three tectonic plates (Euroasian, Indian-Australian and Pacific Plates) between the Pacific and the Indian Oceans and between two big continents (Australia and Asia) (Sutikno, 2007; Marfai et al., 2008). Tsunamis and coastal inundations are very common due to frequent earthquakes and submarine landslides. Approximately 22000 people died because of tsunamis and earthquakes in the Indonesian region during the 20th century (ADRC, 2000). Almost 230000 people died due to the catastrophic tsunami induced by the Great Sumatra Andaman earthquake on 26 December 2004 in western Sumatra, Indonesia (UNESCO/ IOC-NOAA ITIC, 2010). Over the last decade, significant loss of lives, environmental damages and socio-economic losses have increased the interest of researchers, international scientific organizations and governments in tsunamis. Tsunami modeling, early warning systems and paleotsunami researches are important tools to understand the mechanisms of tsunamis, to determine the probability of occurrence in a region, and to prevent or decrease the catastrophic damages of tsunamis and the related losses. 
The Joint Research Centre (JRC) of the European Commission has been operating the Global Disasters Alerts and Coordination System since 2003 (De Groeve et al., 2006; De Groeve, 2007). This system, jointly developed by the European Commission and the United Nations Office for Coordination of Humanitarian Affairs (UN-OCHA), combines existing web-based disaster information management systems with the aim to alert the international community in case of major sudden-onset disasters and to facilitate the coordination of international response teams during the relief phase of the disaster. The GDACS portal is available at http://www.gdacs.org and comprises three elements: (1) Web-based automatic alert notifications and impact estimations for earthquakes, tsunamis, tropical cyclones, volcanic eruptions and floods; (2) a community of emergency managers and emergency operation centers in both responding and disaster-prone countries as well as disaster response organizations worldwide; and (3) an automatic information exchange in web-based disaster information systems (De Groeve et al., 2009).

This paper focuses on the response of the GDACS system to the Kepulaunan Mentawai tsunami that occurred on 25 October 2010 in Indonesia. It also introduces historical tsunami records in the Indian Ocean, seismologic features of the region, description of the event and post-event analyses with different numerical models obtained with the JRC Tsunami Modeling System and JRC Tsunami Analysis Tool (TAT).

\section{Tsunami Early Warning System, scenario database and alerts in GDACS}

Over the centuries large earthquakes have triggered tsunamis bringing death and destruction over a wide area of the world. It soon became clear that these earthquakes could not have been predicted. The time difference between the origin time of an earthquake and the time of arrival of the first tsunami wave makes a Tsunami Early Warning System (TEWS) feasible. The investment in design and installation of a dedicated system can be justified on this basis. However, it is difficult to design TEWSs when a tsunami triggered by an earthquake close to shore reaches coastal areas in a few minutes. But lives can at least be saved in countries more distant from the earthquake's epicenter. Although it is a challenge to design TEWS for the near field tsunamis, the arrival times and maximum heights could be estimated by combining the real time earthquake data with pre-defined sources and precomputed tsunami scenarios.

In the early 60s, after the 1960 Chile Tsunami that caused fatalities also in Japan after $22 \mathrm{~h}$ of wave propagation in the Pacific Ocean, the United Nations Educational Scientific and Cultural Organizations-Intergovernmental Oceanographic Commission (UNESCO-IOC) established the Pacific Tsunami Warning System (PTWS) to alert the coastal countries for the potential of a destructive tsunami wave. This system was based on earthquake parameters (magnitude, lo-

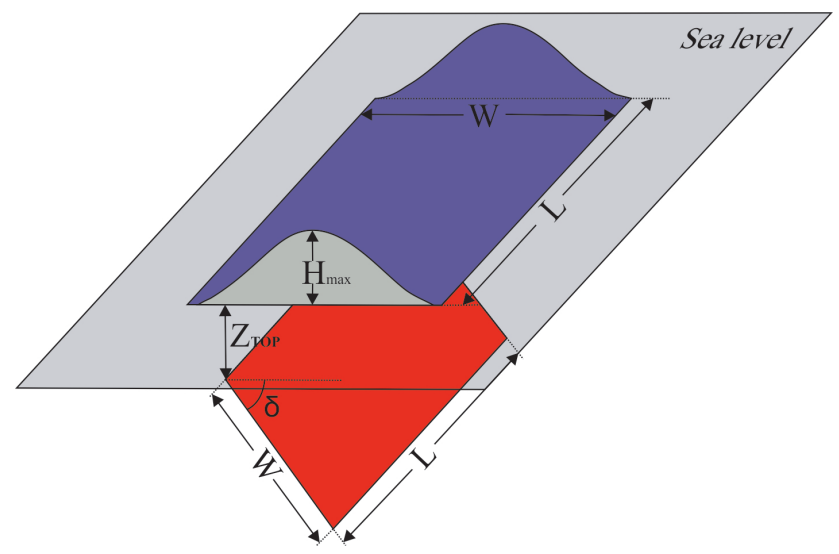

Fig. 1. Fault plane and sea bottom displacement used in the scenario database.

cation and depth) and did not rely on any modeling tool. It was useful over the years to prevent large destruction, in particular for large events.

Numerical tsunami propagation models (MOST, TUNAMI-N2, SHIFT, COMCOT, SWAN, AVI-NAMI, NAMI DANCE, etc) are well developed but they present a challenge to run in real-time, partly due to computational limitations and also due to lack of detailed knowledge of the earthquake rupture details (Titov et al., 2005; Greenslade and Titov, 2008). Thus, the computational methods relying on numerical tsunami propagation are generally based on pre-defined sources and pre-computed tsunami scenarios.

JRC developed a global tsunami modeling system, which is integrated into the GDACS (Annunziato, 2007). Precomputed scenarios are used in order to estimate the alert level as quickly as possible and issue the related warnings to GDACS users. An online calculation system is optimized in order to run immediately whenever a new event or a new revision of an event is available. The system is aimed at estimating the wave arrival times and maximum heights provoked by the earthquakes. A numerical simulation model called SWAN (Mader, 1988) was adapted to the system in order to perform all the grid scenarios calculations. It is initialized and run when a new earthquake is detected. The simulation model solves the non-linear long wave equations of the fluid flow by using a finite-difference scheme (Mader, 1988). The approximation of non-linear long wave equations is performed in geographical coordinates and is adopted to simulate tsunami propagations with an initial displacement of the ocean bottom deformation due to faulting (Fig. 1). It is assumed that this deformation is instantaneous and fully transmitted to the sea surface. Hence, the pre-defined earthquake sources can be modeled as a rectangular fault plane characterized by parameters describing location, orientation, depth, length (L) and width (W) of the fault for different magnitudes. The length and width of the fault can be inferred from empirical studies since the true fault plane can only be estimated by applying inversion techniques to teleseismic waves. 


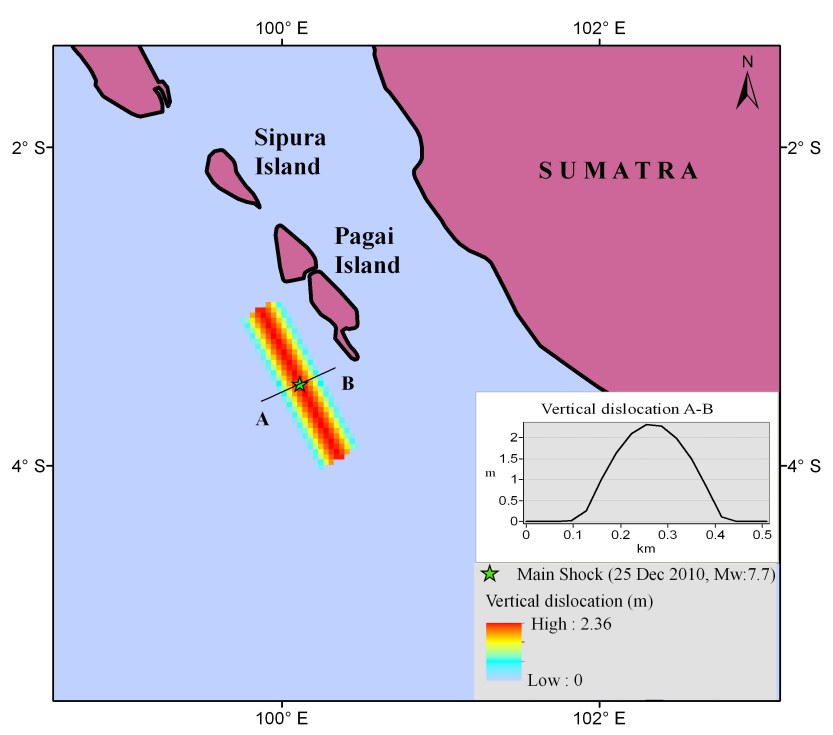

Fig. 2. Initial cosinusoidal hump tsunami source of the $2010 \mathrm{Kepu}-$ launan Mentawai event.

The calculation parameters of the fault, currently assumed in both the scenario and the online calculations, were calculated by using empirical equations as a function of magnitude, which can be expressed as follows (Utsu et al., 2001; Ward, 2002):

$\log \mathrm{L}=0.5 \mathrm{M}-1.8$

$\mathrm{W}=\mathrm{L} / 3.5$

where $\mathrm{L}, \mathrm{W}$ and $\mathrm{M}$ are fault length $(\mathrm{km})$, width $(\mathrm{km})$ and magnitude, respectively. Relationship between the length and average slip was used as in the following equation (Ward, 2002):

$\Delta u=2 \times 10^{-5} \mathrm{~L}$

where $\Delta u$ is the average slip in meters and $\mathrm{L}$ is the length of the fault in kilometers. The form of the wave is obtained from a half cosine with a maximum amplitude given by the relation (1). This form is an arbitrary choice that links the tsunami height at the source to the earthquake slip on the fault. The initial cosinusoidal hump sources for the vertical deformation of the sea floor are calculated for each point of the grid in the database. Figure 2 shows the initial cosinusoidal hump tsunami source of the 2010 Kepulaunan Mentawai event due to the magnitude of 7.7 that issued an orange alert in the GDACS system. This form is very close to a very shallow focal depth and represents a "worst case" scenario for the establishment of the maximum height.

The prepared scenario database includes pre-computed cases obtained by considering all the known historical events. Around every historical event a grid of $10 \times 10$ data points at 0.5 degrees interval has been identified (Fig. 3), leading to
10180 potential source epicenters; additional 280 epicenters have also been included to complete some areas in the Gulf of Cadiz (Annunziato et al., 2009). For each point of the grid, calculations in the magnitude range from 6.5 to 9.5 with interval of 0.25 have been performed, for a total of $136000 \mathrm{cal}-$ culations covering all the tsunamigenic regions of the World Oceans. The fault strike was assigned to be parallel to the orientation of plate boundaries since the majority of fault strikes are parallel to the orientation of plate boundaries in subduction areas.

The pre-defined calculations were performed with a calculation grid varying from 1 to 20 arc-min, depending on the size of the magnitude. The larger events have a greater propagation extent and therefore the grid cell size is increased in order to keep the running time reasonable. The choice to use large grid size may have an influence for particularly large events; this is why a new database is being prepared with a different criterion that guarantees smaller grid cell size close to the coast and the new calculations are in progress. The predefined calculations were performed using resampled values from ETOPO2 (2006) bathymetry data. The scenario calculations do not consider the depth as a parameter; therefore in the GDACS evaluation of the events, the highest wave height calculated for any given scenario is multiplied by a factor which is a function of the magnitude and the depth, in order to account for the reduction due to the location of the hypocenter since deep earthquakes could generate smaller sea level deformations. The reduction coefficient function has been obtained by analyzing the effect of the depth on the initial sea level deformation conditions, running Monte Carlo Simulations for several width/length/depth combinations and adopting an Okada (1985) model; from these simulations the following relation was derived:

$\mathrm{H}=\mathrm{H}_{5 \mathrm{~km}} * \mathrm{f}$ (mag, depth),

where $\mathrm{H}_{5} \mathrm{~km}$ is the initial height with a depth of $5 \mathrm{~km}$ and $\mathrm{H}$ is the initial height for the current depth (Table 3). For example, the depth factor is calculated 0.8 for a depth of $18 \mathrm{~km}$ (Fig. 4). Thus, the calculated wave height of $3.16 \mathrm{~m}$ is reduced to $2.5 \mathrm{~m}$. However, the depth factor was not used for the near real-time and post-event calculations.

The next important step is to retrieve tsunami heights and arrival times from the database. The system works by using the data notified to JRC by the seismological organizations. At the moment, JRC has concluded agreements with several international seismological organizations such as National Earthquake Information Center (NEIC), NEIC, National Oceanic and Atmospheric Administration (NOAA), European Mediterranean Seismological Centre (EMSC) plus other national Institutions such as Institute of Meteorology (IM), Portugal, Kandilli Observatory Earthquake and Research Institute (KOERI), Turkey and National Observatory of Athens (NOA), Greece, which write new records related to every new event or revision into the JRC system, a so-called "push system". When a new earthquake is added 


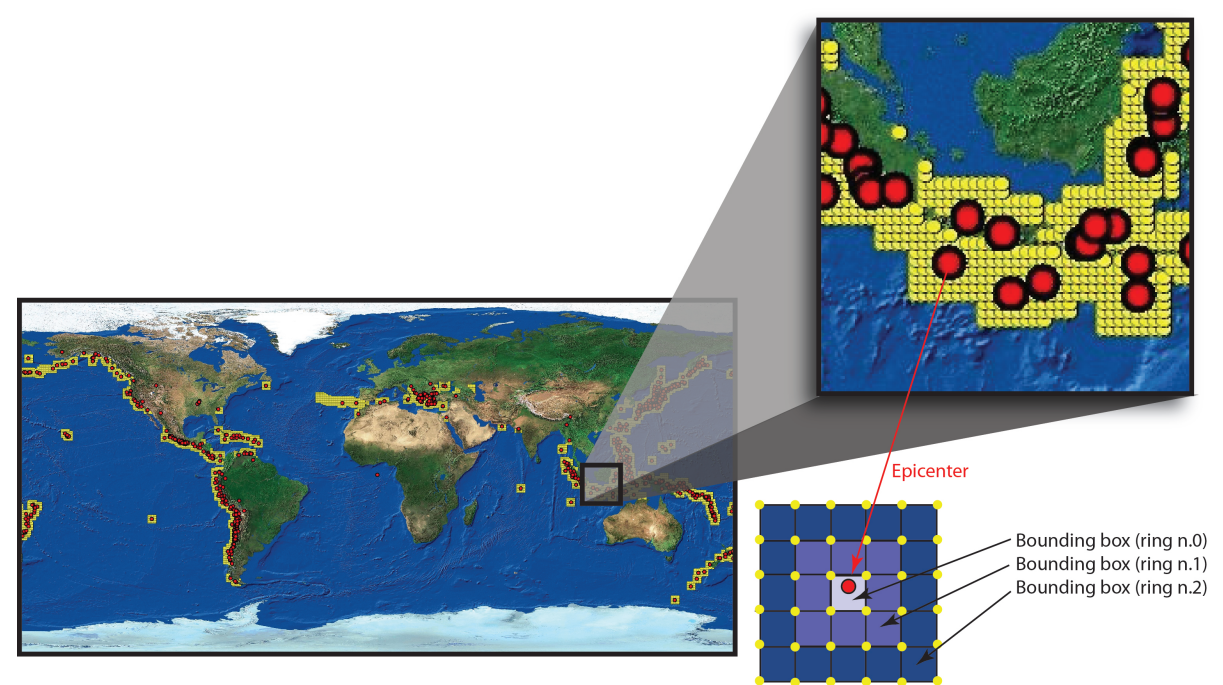

Fig. 3. Schematic representation of individual grid boundaries and historical tsunami earthquake locations (modified from Annunziato, 2007).

Table 1. GDACS and TSUNAMI alert levels.

\begin{tabular}{lll}
\hline & Alert Level & International Relevance \\
\hline GDACS & Green Alert & Very low likelihood of humanitarian disaster, affected country can mostly cope \\
& Orange Alert & Potential humanitarian disaster, affected country can probably cope \\
& Red Alert & Very high likelihood of humanitarian disaster, international assistance possibly needed \\
\hline \multirow{3}{*}{ TSUNAMI } & Green Alert & Maximum height is lower than $1 \mathrm{~m}$ \\
& Orange Alert & Maximum height is between 1 and $3 \mathrm{~m}$ \\
& Red Alert & Maximum height is greater or equal than $3 \mathrm{~m}$ \\
\hline
\end{tabular}

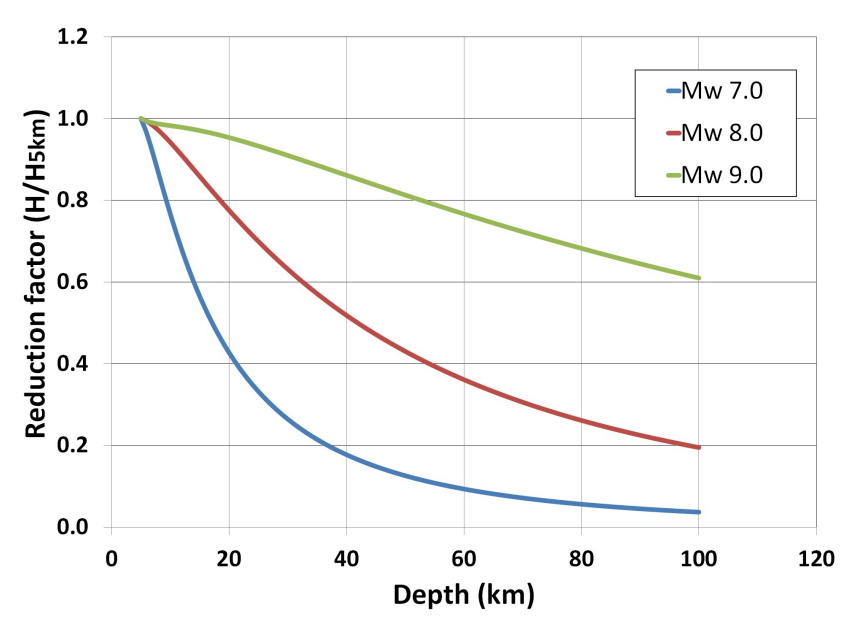

Fig. 4. The reduction factors due to the depth of the fault for the magnitudes of 7.0, 8.0 and 9.0. to the JRC repository, GDACS chooses the most appropriate data from the scenario database which match the detected earthquake according to the epicenter location and magnitude. If a scenario calculation is available for that point, the earliest arrival times and the maximum tsunami heights at each coastal settlement are retrieved. The maximum height is used by the GDACS to establish the alert level according to a simple logic (Table 1) and eventually used to create alert reports sent to the registered users by mail, fax or SMS.

In addition to the scenario pre-computed data, all revised epicenter and magnitude data are also used in order to initialize an online calculation. In general, this calculation is more accurate because it is initialized with the revised earthquake parameters while the previous one is just the closest match in the database. The on-line calculations are also available to the users accessing the GDACS website but these cannot be useful for the alerting logic because the online calculations take about $30-40 \mathrm{~min}$ to be completed. The flowchart of GDACS web applications for earthquake and tsunami alerts is shown in Fig. 5. 
Table 2. List of historical tsunami records in the Indian Ocean (Dominey-Howes et al., 2007).

\begin{tabular}{|c|c|c|c|c|c|}
\hline Year & Date & $\begin{array}{l}\text { Tsunami Source } \\
\text { (Trigger mechanism/area) }\end{array}$ & M & $\begin{array}{r}\text { Maximum } \\
\text { Run-up (m) }\end{array}$ & Deaths/effects/comments \\
\hline $326 \mathrm{BC}$ & & Unknown Source/Mouth of River Indus & & & Macedonian fleet destroyed \\
\hline 1008 & & Earthquake on Persian Gulf Coast & & & \\
\hline 1524 & & Unknown Source/Gulf of Cambay & & & \\
\hline 1762 & $2 \mathrm{Apr}$ & Earthquake on Arakan coast (Myanmar) & & & Many Deaths? \\
\hline 1770 & & Earthquake S Sumatra & & & \\
\hline 1797 & $10-11 \mathrm{Feb}$ & Earthquake W Sumatra & $8.5-8.7$ & & \\
\hline 1819 & $18 \mathrm{Mar}$ & Earthquake S Sumatra & & & \\
\hline 1833 & $24 \mathrm{Nov}$ & Earthquake W Sumatra & $8.7-9.2$ & & \\
\hline 1842 & $11 \mathrm{Nov}$ & Bay of Bengal & & & \\
\hline 1843 & 5-6 Jan & Earthquake N Sumatra & & & \\
\hline 1874 & 31 Oct & Earthquake Nicobar Is. & & & \\
\hline 1861 & 16 Feb & Earthquake N Sumatra & $8.3-8.5$ & 7 & \\
\hline 1868 & 19 Aug & Earthquake Andaman Is. & & 4 & \\
\hline 1881 & $31 \mathrm{Dec}$ & Earthquake Nicobar Is. & 7.1 & 1 & \\
\hline 1882 & ? Jan & Unknown/Sri Lanka & & & \\
\hline 1883 & 27 Aug & Krakatoa eruption/Sunda strait & & 35 & 36000 \\
\hline 1886 & & Unknown/Bay of Bengal & & & \\
\hline 1907 & 4 Jan & Earthquake NW Sumatra & 7.6 & & \\
\hline 1921 & 11 Sep & Earthquake Java & 7.5 & & \\
\hline 1941 & 26 Jun & Earthquake Andaman Is. & 7.7 & & $5000 ?$ \\
\hline 1945 & 27 Nov & Earthquake Makran coast & 8.1 & 15 & \\
\hline 1977 & 19 Aug & Earthquake Java & 8.3 & 30 & \\
\hline 1994 & 2 Jun & Earthquake Java & 7.6 & 13 & 200 \\
\hline 2004 & $26 \mathrm{Dec}$ & Earthquake NW Sumatra- Andaman Island & $9.0-9.3$ & $31-49$ & 230000 \\
\hline 2005 & $28 \mathrm{Mar}$ & Earthquake NW Sumatra & 8.7 & 3 & \\
\hline 2006 & 17 July & Earthquake Java & 7.7 & & 664 \\
\hline 2007 & 12 Sep & Earthquake Bengkulu & 8.4 & & \\
\hline 2009 & 30 Sep & Earthquake Padang & 7.5 & & \\
\hline 2010 & 25 Oct & Earthquake Kepulaunan Mentawai & $7.7 *$ & $3-9 * *$ & $431 * *$ \\
\hline
\end{tabular}

* USGS (2010c) ** Lay et al. (2011a)

In general the GDACS alerts are based on three classes according to the likelihood of humanitarian disasters, international assistance possibility and expected maximum tsunami heights (Table 1). These classes are created by the risk models and selected by a computer program based on the earliest available information of an event. GDACS combines information on the event, the population in the affected area and the vulnerability of that population to derive an alert level that indicates the probability for a catastrophic situation requiring international humanitarian intervention. In the case of a tsunami, the alerting level does not depend on the population density around the epicenter because it may well happen that the waves can travel thousands of $\mathrm{km}$ and still put at risk coastal populations. Therefore, the alert logic is only based on the expected maximum height in populated locations for the tsunamis.

\section{Historical Tsunami records in the Indian Ocean}

A detailed archival research on the propagation mechanism and impact of historical tsunamis is necessary for better understanding the records and effects of tsunamis in the Indian Ocean and for estimating the probability of occurrence in the future (Dominey-Howes et al., 2007). Vulnerable coastal areas for tsunamis in Indonesia are shown in Fig. 6.

The records of past tsunamis generated in or affecting a particular region are necessary to determine the probability of the occurrence of a tsunami with a specific size in a certain period. Such a list of historical records can be used to sketch the graph of a frequency-recurrence curve and estimate return periods for events of different magnitudes. Therefore, historical records should extend back for a long time period and be as accurate as possible (Dominey-Howes, 2002). Table 2 lists the historical tsunami records in the Indian Ocean.

Natawidjaja et al. (2006) described the 1797 earthquake in Padang: "In 1797 Padang was a tiny English colonial settlement $1-2 \mathrm{~km}$ upstream from the coast on the banks of a small 


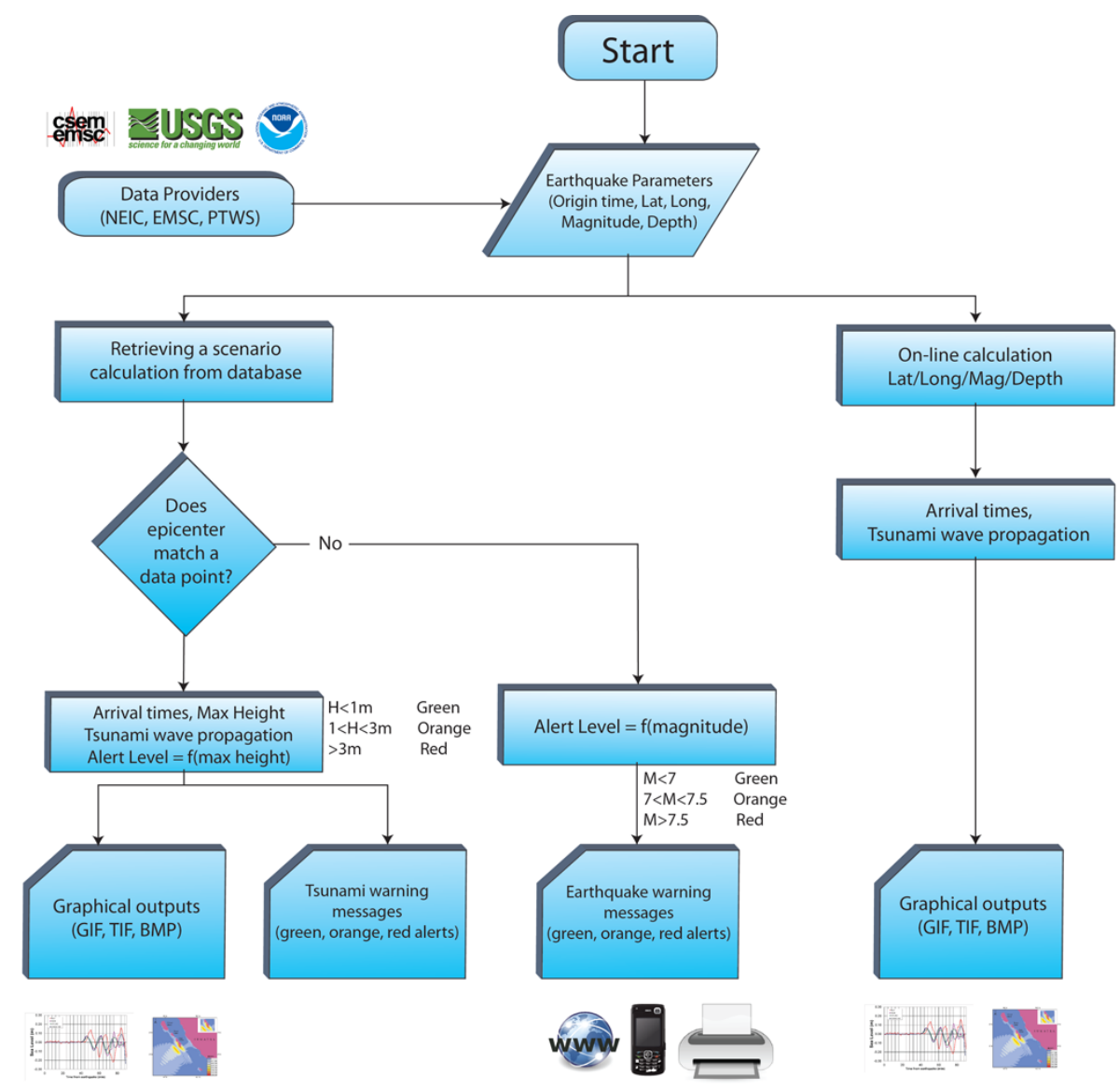

Fig. 5. Flowchart of earthquake and tsunami alert web application in GDACS.

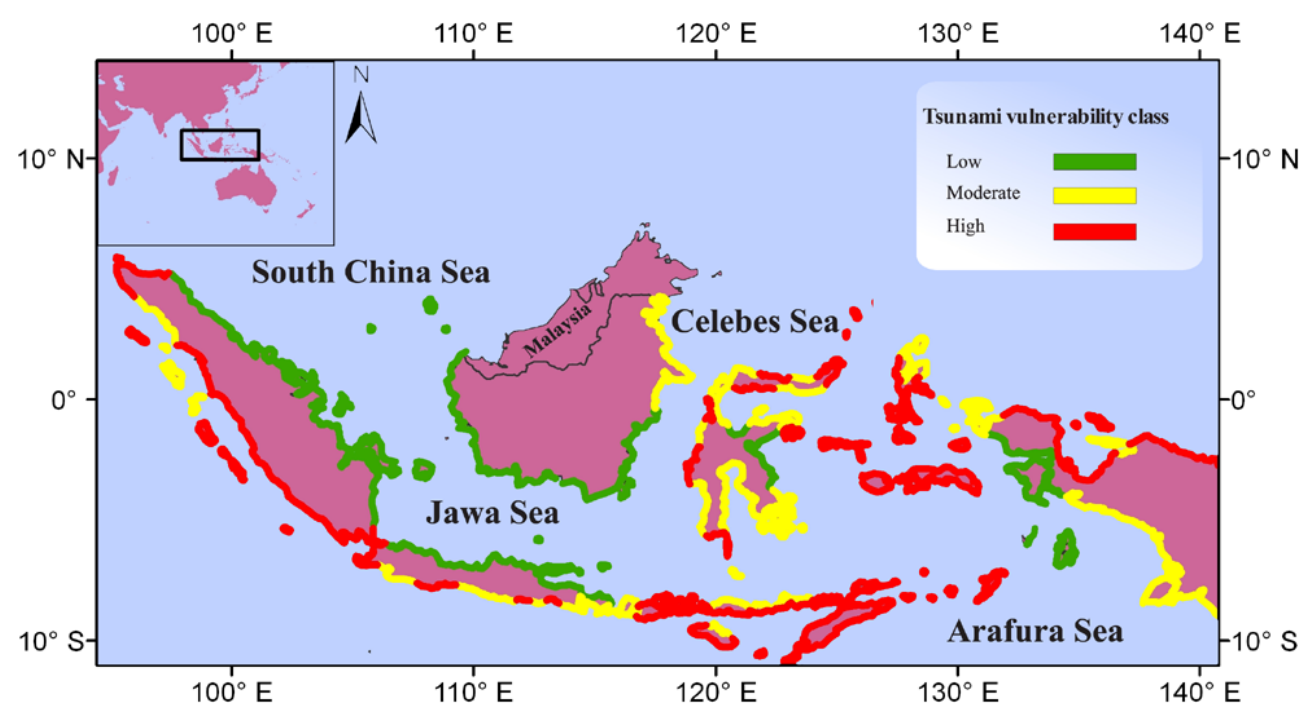

Fig. 6. Coastal vulnerable areas to tsunami in Indonesia (Compiled from those of BKSPN, 2006).

river. The tsunami ran up the river and according to contemporary accounts it picked up a 150-ton English sailing vessel that was moored near the river mouth, carried it up the river and deposited it over the river bank in the middle of town. That would have required an overland flow depth of several meters". Padang now has a population over 800000 . The 
effects of the 1797 tsunami would be catastrophic today. The 1833 tsunami affected Bengkulu destructively (Sieh, 2007). Today, the population that could be affected by a tsunami in Bengkulu, Padang, Mentawai Islands and the other coastal cities in Western Sumatra is more than a million. The analyses of the 1797 and 1833 tsunamis and scenarios showed that residents of coastal West Sumatra and Bengkulu provinces are at risk from tsunami surges that will result from the next great ruptures of the Sunda megathrust beneath the Mentawai Islands (Borrero et al., 2006).

\section{Seismotectonics properties of the region}

The Kepulaunan Mentawai Earthquake of 25 October 2010 occurred near the subduction interface plate boundary between the Australian and Sunda plates. The Australian plate moves relative to the Sunda plate in the region. The plates meet at the Sunda trench, a subduction zone that extends from Myanmar to south past Sumatra and Java and east toward Australia. The subduction zone is a part of long convergent belt in the region (Fig. 7). This subduction zone is one of the most seismically active regions in the world. Earthquakes frequently occur along the Sunda trench and the Sumatra fault. Five earthquakes with $M_{\mathrm{w}}>8.0$ have happened in the region within the last two centuries as shown in Table 2, including the recent $M_{\mathrm{w}}=9.0$ event on 26 December 2004. The Sunda trench is considered a megathrust fault. Thus, this region has a high possibility of generating tsunamis. A better understanding of the tectonics and rupture process in the region is important for evaluating the possible consequences of the future tsunamis for risk mitigation.

The rate of relative plate motion varies from east to west across the region. Interplate earthquakes occur as the result of seismic slip on the thrust boundary between the overriding Sunda plate and the subducting Australian plate (USGS, 2010a). The arrows shown in Fig. 7 indicate the relative velocities of the plate pairs. According to the arrows in the same figure, the Australian and the Sunda plates are colliding at about a rate of $60 \mathrm{~mm}$ per year. This collision between plates enables an increasing of the stress over time, making possible a sudden energy release in the form of earthquakes and rupturing. This is the simple interaction of the Australian and Sunda plates. However, the situation is more complex since deformation of the overriding plate leads to larger complexities in plate motions (McCaffrey, 2009). Sumatra sits at the southwestern edge of the Sunda plate (Bird, 2003), which moves at a few millimeters per year to a centimeter per year eastward relative to Eurasia (Chamot-Rooke and Le Pichon, 1999; Bock et al., 2003) (Fig. 7). Fitch (1972) explained the presence of the Sumatran fault and other similar faults inboard subduction zones by the process known as slip partitioning. Slip partitioning in the region controls also the mechanisms of the faults that may cause the big earthquakes in the region (McCaffrey, 2009). In the case of slip partitioning, one fault is the subduction thrust, which takes up all of the trench-normal slip (the dip-slip component) and some fraction of the trench-parallel slip (the strike-slip component). A second fault, within the overriding plate and commonly strike-slip in nature, takes up a portion of the trenchparallel motion. The subduction thrust and strike-slip fault isolate a wedge of forearc called the sliver plate. The epicenter of the 25 October 2010 Kepulaunan Mentawai earthquake, aftershock distribution and proposed fault mechanism from the USGSs moment tensor solutions (USGS, 2010b) enable the earthquake as a trust faulting on or near the subduction interface plate boundary between the Australian and Sunda plates (Fig. 8).

\section{Kepulaunan Mentawai Earthquake Tsunami and GDACS response}

On 25 October 2010 14:42:22 UTC, an earthquake of magnitude 7.7 and depth $20.6 \mathrm{~km}$ struck the unpopulated Kepulauan Mentawai Region in Sumatera Barat Province in Indonesia. The epicenter of the earthquake (Lon: $100.114^{\circ} \mathrm{E}$, Lat: $3.484^{\circ} \mathrm{S}$ ) was located $240 \mathrm{~km}$ west of Bengkulu, $280 \mathrm{~km}$ south of Padang and $305 \mathrm{~km}$ west of Lubuklingau (USGS, 2010c). This earthquake generated 3 to $9 \mathrm{~m}$ tsunami run-up along southwestern coasts of the Pagai Islands that took at least 431 lives (Lay et al., 2011a). The population density in the radius of $200 \mathrm{~km}$ is 3 people $\mathrm{km}^{-2}$ and population density near epicenter is given in Fig. 9 (JRC, 2010). Since the population density is low near the epicenter, the number of affected people was not as large as could be expected. Locations and damage extent maps of Sibugau Island and the South Pagai coasts are displayed in Figs. 10 and 11, respectively. The red dash line symbolizes inundation line. The boundaries of inundation can be observed in Fig. 11 and they make visible the enormity of the event. The Indonesian Disaster Management Agency (BNPB) confirmed 545 heavily damaged and 204 slightly damaged houses in the district. Schools, offices, places of worship and infrastructures such bridges were also damaged. It was estimated that 7397 internally displaced persons have been forced to flee their homes due to the disaster (OCHA, 2011).

Five minutes after the earthquake, the Indonesia Meteorological, Climatological and Geophysical Agency (Badan Meterologi Kilimatologi dan Geofisika) issued a national warning for a local tsunami. Japan Meteorological Agency reported local tsunami watch $19 \mathrm{~min}$ after the occurrence (UNESCO/IOC-NOAA ITIC, 2010). GDACS received the first event information from PTWS (Pacific Tsunami Warning System) $7 \mathrm{~min}$ after the event. The preliminary earthquake parameters, Lat: $-3.4^{\circ} \mathrm{S}$, Lon: $99.99^{\circ} \mathrm{E}$, magnitude $7.2\left(M_{\mathrm{w}}\right)$ and hypocenter at $53 \mathrm{~km}$, was issued and pushed to the GDACS system by European Mediterranean Seismological Centre (EMSC) $11 \mathrm{~min}$ after the event (Table 3). At that time, the pre-calculated tsunami simulation 


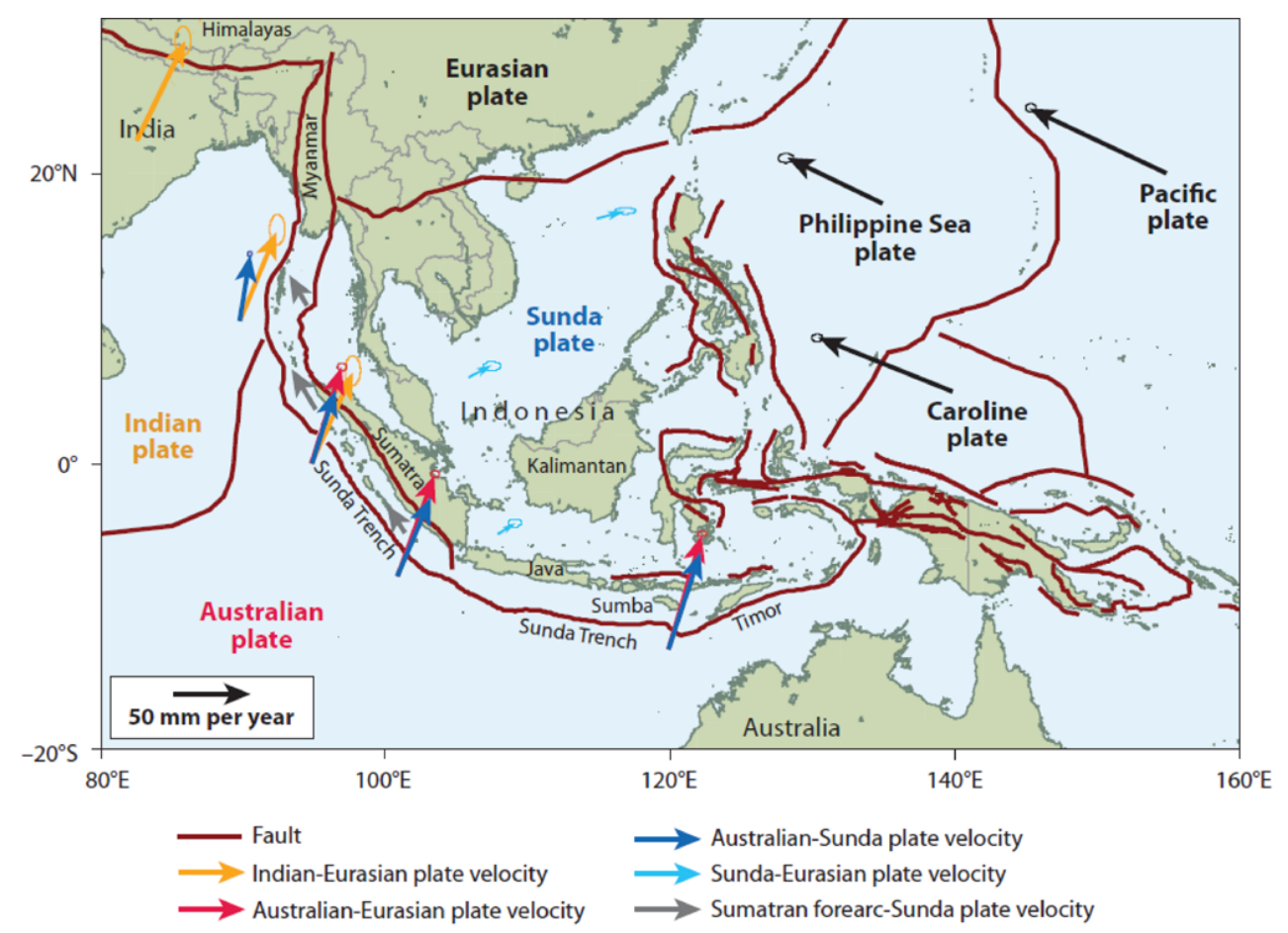

Fig. 7. Tectonic setting of the region (McCaffrey, 2009).

Table 3. The timeline of the preliminary earthquake parameters pushed to the GDACS system on 25 October 2010 (GDACS, $2010 \mathrm{~b}$ ).

\begin{tabular}{|c|c|c|c|c|c|c|c|c|c|}
\hline $\begin{array}{l}\text { Earthquake } \\
\text { Report* }\end{array}$ & $\begin{array}{l}\text { Tsunami } \\
\text { Report** }\end{array}$ & Lat $\left(^{\circ}\right)$ & $\operatorname{Lon}\left(^{\circ}\right)$ & M & $\begin{array}{l}\text { Depth } \\
(\mathrm{km})\end{array}$ & $\begin{array}{l}\text { Reduction } \\
\text { Factor }\end{array}$ & Source & $\begin{array}{l}\text { Publication } \\
\text { Date Time }\end{array}$ & Delay \\
\hline 696084 & $2261(0.0 \mathrm{~m})$ & -3.1 & 99.99 & 7.2 & 53 & 0.10 & EMSC & 14:54:07 UTC & $11 \mathrm{~min}$ \\
\hline 696085 & $2263(0.6 \mathrm{~m})$ & -3.1 & 100.2 & 7.5 & 33 & 0.40 & NOAA & 14:59:30 UTC & $17 \mathrm{~min}$ \\
\hline 996086 & $2264(0.1 \mathrm{~m})$ & -3.34 & 100.1 & 7.2 & 30 & 0.33 & EMSC & 14:59:38 UTC & $17 \mathrm{~min}$ \\
\hline 696087 & $2265(0.1 \mathrm{~m})$ & -3.44 & 100.06 & 7.0 & 10 & 0.77 & EMSC & 15:06:28 UTC & $24 \mathrm{~min}$ \\
\hline 696088 & $2266(0.3 \mathrm{~m})$ & -3.45 & 100.15 & 7.3 & 10 & 0.84 & EMSC & 15:09:38 UTC & $27 \mathrm{~min}$ \\
\hline 696089 & $2267(0.6 \mathrm{~m})$ & -3.468 & 100.0839 & 7.5 & 14.2 & 0.75 & NEIC & 15:15:07 UTC & $32 \mathrm{~min}$ \\
\hline 696091 & $2267(0.6 \mathrm{~m})$ & -3.4638 & 100.0839 & 7.5 & 14.2 & 0.75 & NEIC & 15:19:07 UTC & $36 \mathrm{~min}$ \\
\hline 696093 & $2267(0.6 \mathrm{~m})$ & -3.4638 & 100.0839 & 7.5 & 14.2 & 0.75 & NEIC & 15:21:37 UTC & $39 \mathrm{~min}$ \\
\hline 96106 & $2267(0.4 \mathrm{~m})$ & -3.841 & 100.1139 & 7.5 & 20.6 & 0.60 & NEIC & 16:50:15 UTC & $127 \mathrm{~min}$ \\
\hline 96108 & $2268(1.0 \mathrm{~m})$ & -3.4841 & 100.1139 & 7.7 & 20.6 & 0.67 & NEIC & 17:20:15 UTC & $157 \mathrm{~min}$ \\
\hline 96114 & $2269(0.8 \mathrm{~m})$ & -3.46 & 100.12 & 7.6 & 10 & 0.89 & EMSC & 17:52:15 UTC & $189 \min$ \\
\hline 96232 & $2268(0.9 \mathrm{~m})$ & -3.46 & 100.12 & 7.7 & 10 & 0.91 & EMSC & 06:27:47 UTC & $945 \min$ \\
\hline 96318 & $2266(0.2 \mathrm{~m})$ & -3.4841 & 100.1139 & 7.3 & 20.6 & 0.52 & NEIC & 14:58:19 UTC & $1455 \mathrm{~min}$ \\
\hline 113405 & $2268(1.0 \mathrm{~m})$ & -3.4841 & 100.1139 & 7.7 & 20.6 & 0.67 & NEIC & 17:35:17 UTC & $1612 \mathrm{~min}$ \\
\hline
\end{tabular}

* Earthquake alert levels and report numbers, ${ }^{* *}$ Tsunami report numbers and maximum heights at coast.

was retrieved from the scenario database whose epicenter is located in the nearest grid point to the issued earthquake location. The nearest grid point is in $-3.5^{\circ} \mathrm{S}, 100^{\circ} \mathrm{E}$ and the magnitude is 7.25 in the database. The earliest arrival times and the maximum tsunami heights at each coastal settlement were retrieved from the calculations of that grid point (Table 4). The alert logic for the earthquake indicated low humanitarian impact since the affected region was unpopulated and had medium resilience for natural disasters, while the logic for tsunami indicated a minor event since the estimated height was lower than $1 \mathrm{~m}$; therefore the alert level was defined as green. After the first estimation, GDACS continuously evaluated the earthquake and tsunami impact as the data continued to be provided from international seismological organizations. Correspondingly, GDACS estimated higher or lower heights depending on the 


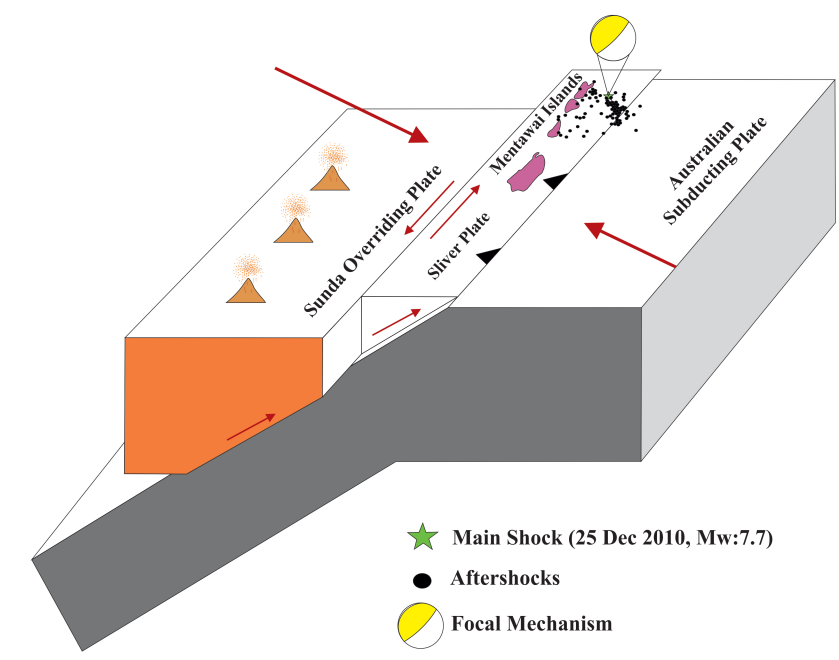

Fig. 8. The geometry of the overriding, sliver and subducting plates around the Mentawai Islands with the aftershock distiribution of the 25 October 2010 Kepulaunan Mentawai earthquake (Modified from McCaffrey, 2009).

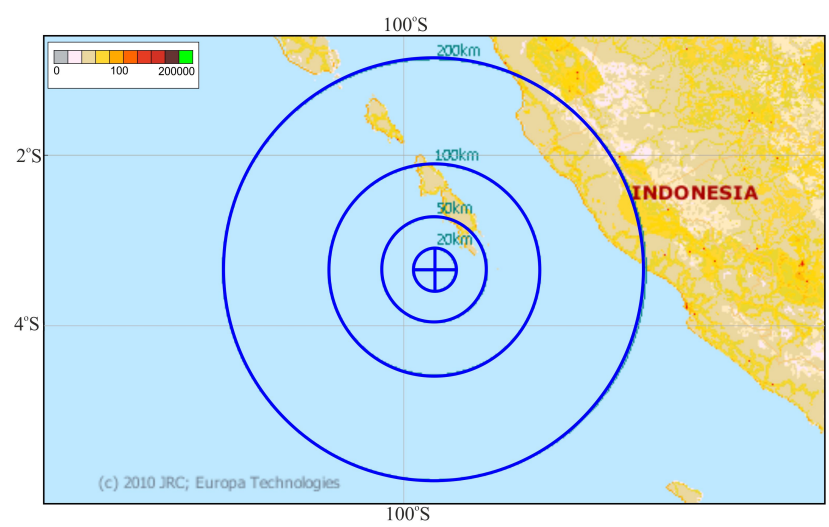

Fig. 9. Population density near epicenter (people $\left.\mathrm{km}^{-2}\right)(\mathrm{JRC}$, 2010).

issued magnitude, location and depth, based on the results of the pre-calculated scenarios. An evaluation after $2 \mathrm{~h}$ and 17 min by using the earthquake parameters of NEIC (report number, 96108 in Table 3) with a magnitude of 7.7 and depth $20.7 \mathrm{~km}$ caused an estimation of $1 \mathrm{~m}$ tsunami height in Beleratsok, Mentawai Island, and therefore the orange alert was issued. At that time GDACS automatically sent out $14000 \mathrm{e}-$ mails and SMS. The further estimations of the earthquake parameters issued by international seismological organizations temporarily reduced the alert level again until it was definitely set to Orange because the final magnitude estimation of the earthquake was 7.7 and depth $20 \mathrm{~km}$. First report in the international media was published $2 \mathrm{~h} 18 \mathrm{~min}$ after the event by Reuters News Wire (EMM, 2010). The last automatic report of the GDACS was published 1 day and 15 min after the event. In the final report, the alert level was defined as or-

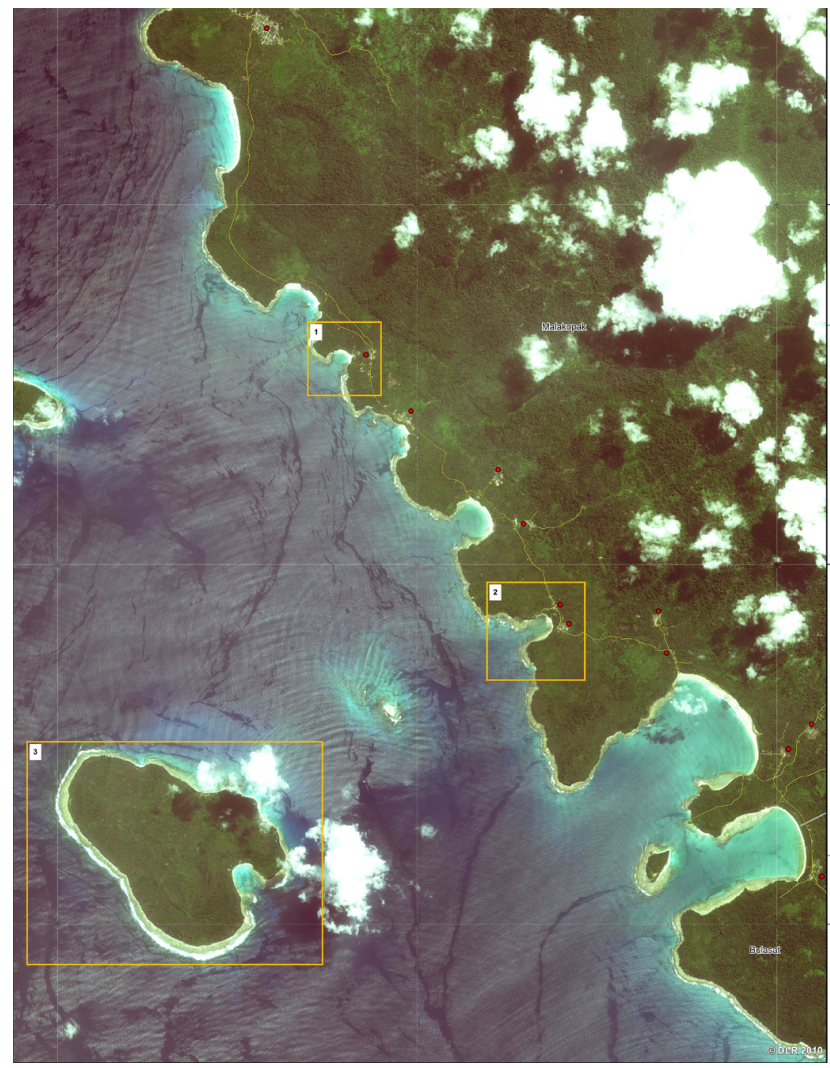

Fig. 10. Sibugau Island and South Pagai coast (ReliefWeb, 2011).

Table 4. The first listed arrival times and maximum heights retrieved from the pre-calculated database by using the preliminary results of EMSC.

\begin{tabular}{crlc}
$\begin{array}{c}\text { Time from } \\
\text { event }\end{array}$ & $\begin{array}{r}\text { Actual } \\
\text { time }\end{array}$ & Location & $\begin{array}{c}\text { Height } \\
(\mathrm{m})\end{array}$ \\
\hline $00: 22$ & $25 / 10 / 201015: 04: 07$ & Taigebgem & 0.3 \\
$00: 22$ & $25 / 10 / 201015: 04: 44$ & Beleratsok & 0.5 \\
$00: 23$ & $25 / 10 / 201015: 05: 20$ & Siberimanua & 0.3 \\
$00: 23$ & $25 / 10 / 201015: 05: 57$ & Simagandjo & 0.2 \\
$00: 24$ & $25 / 10 / 201015: 06: 34$ & Pasapuat & 0.2 \\
$00: 27$ & $25 / 10 / 201015: 09: 38$ & Maileppet & 0.2 \\
$00: 31$ & $25 / 10 / 201015: 13: 16$ & Pasigoppa & 0.1 \\
$00: 33$ & $25 / 10 / 201015: 15: 07$ & Sibadoeggo & 0.1 \\
$00: 36$ & $25 / 10 / 201015: 18: 48$ & Kagogolo & 0.1 \\
$00: 38$ & $25 / 10 / 201015: 20: 38$ & Simokko & 0.1 \\
$00: 39$ & $25 / 10 / 201015: 21: 15$ & Gigitji & 0.2 \\
$00: 44$ & $25 / 10 / 201015: 26: 10$ & Patdarai & 0.1 \\
$00: 45$ & $25 / 10 / 201015: 27: 23$ & Hilibafunua & 0.1 \\
$00: 55$ & $25 / 10 / 201015: 37: 12$ & Silaoinan & 0.2 \\
$00: 57$ & $25 / 10 / 201015: 39: 40$ & Seai & 0.2 \\
$01: 00$ & $25 / 10 / 201015: 42: 01$ & Buriai & 0.2 \\
$01: 00$ & $25 / 10 / 201015: 42: 01$ & Sabeugukgung & 0.3 \\
$01: 00$ & $25 / 10 / 201015: 42: 01$ & Tiop & 0.3 \\
\hline
\end{tabular}



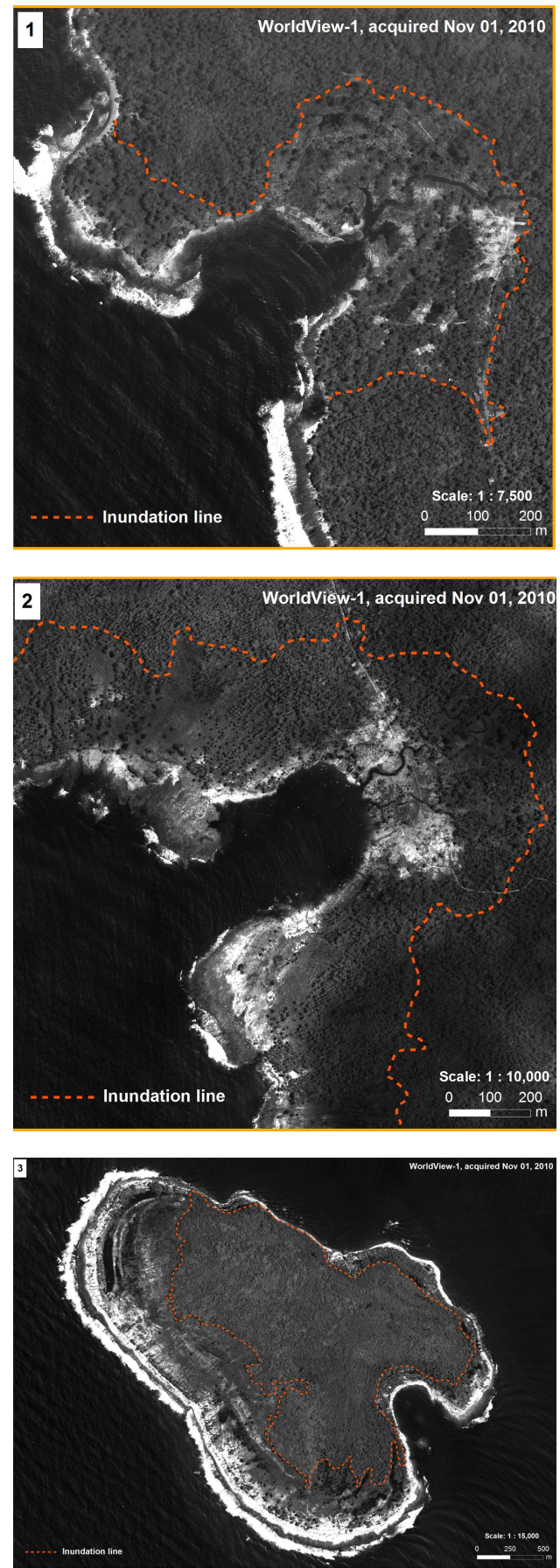

Fig. 11. Damage Extent Map (Reliefweb, 2010).

ange. It was assumed that in the orange level there should be a tsunami generated and the maximum tsunami wave height was estimated $1.5 \mathrm{~m}$ near the coast of Beleratsok (GDACS, 2010b).

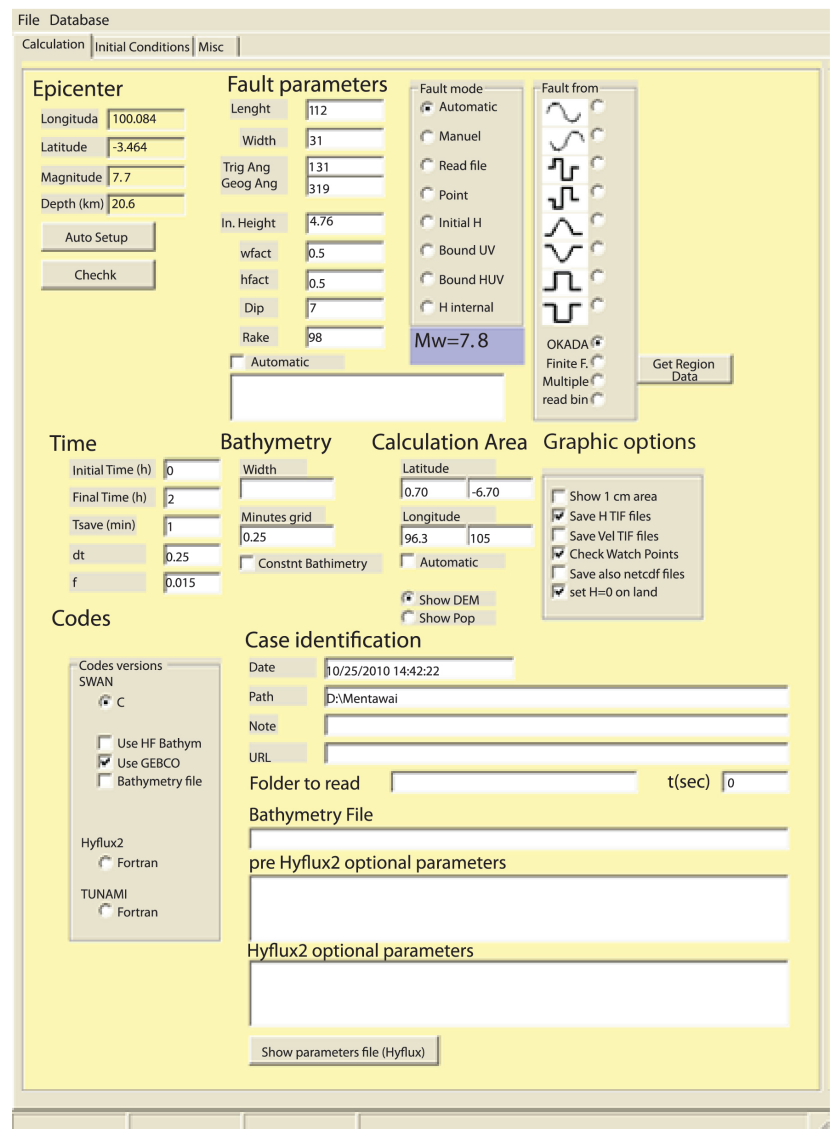

Fig. 12. Input window of the program interface.

The GDACS system was originally designed as an automatic system which uses the preliminary earthquake parameters pushed by different seismological organizations, without relying on manual analysis of the sea level measurements in the area. It was clear, however, from the analysis of the measured sea level values, that the level was higher than estimated. It is important to understand the reasons for these differences in order to improve the system when similar events occur in that area.

\section{Post-event analysis}

Although the GDACS system connected with the tsunami scenario database is used on a global scale for near real-time alerts and early warnings, it may overestimate or underestimate tsunami heights due to incorrect initial parameters. In order to improve the results, it has been necessary to take into account the tectonic setting and seismicity of the region and surrounding area. It is important to take into account the fault mechanism solutions, not simply by using epicenter, length, width and depth. The analysis was performed by considering the form of focal mechanism solutions in relation to which the fault plane is responsible for the tsunami. 
However, it is still a challenge for researchers to define the focal mechanism solutions such as strike, dip, slip, and rupture velocity of the fault in a real time immediately after an earthquake.

In this section, the modeling of the 25 October 2010 Kepulauan Mentawai tsunami was analysed by using earthquake parameters and fault mechanism solutions provided by USGS (USGS, 2010b). The initial condition of the tsunami was prescribed as an elevation of sea level identical to the vertical co-seismic displacement of the sea floor and determined from linear elastic dislocation theory (Okada, 1985). Hence, the earthquake source was modeled as a rupture of a single rectangular fault plane characterized by parameters describing location, orientation, dip, rake angle and rupture direction. The source parameters were referenced as GCMT (Global Centroid Moment Tensors) solutions for this event. The strike, dip and rake of the fault derived from the GCMTs for large worldwide earthquakes using long period surface waves were given as $319^{\circ}, 7^{\circ}$ and $98^{\circ}$ for the nodal plane1 (NP1) and as $131^{\circ}, 83^{\circ}$, and $89^{\circ}$ for the nodal plane2 (NP2), respectively (USGS, 2010b). It is not possible to determine solely from a focal mechanism which of the nodal planes is in fact the fault plane. Thus, by taking into account the known tectonic features of the subduction in the region, the NP1 was chosen as the main nodal plane. A rectangular fault model and average uniform slip was assumed for the dislocation area (Fig. 13). The length and width of the fault was obtained by available empirical relations of scaling low in Eqs. (1) and (2). The amount of average uniform slip was computed using the following equations:

$M_{0}=\mu \mathrm{DLW}$

$M_{\mathrm{w}}=\frac{2}{3} \log _{10} M_{0}-10.7$

where $\mu$ is the rigidity of earth crust, D is the amount of average slip motion, $\mathrm{L}$ and $\mathrm{W}$ are respectively the length and width of the fault plane, $M_{0}$ is the scalar moment of an earthquake and $M_{\mathrm{w}}$ is the moment magnitude of an earthquake (Aki, 1966; Hanks and Kanamori, 1979). The earthquake source parameters and their units are given in Table 5. The crustal rigidity assumed for the numerical simulation is $4.0 \times 10^{11} \mathrm{dyn} \mathrm{cm}^{-2}$.

A user interface developed by Annunziato (2007) was used to simulate the tsunami propagation by using the postevent parameters of 2010 Kepulaunan Mentawai Earthquake. It is in the form of a user friendly Windows programme which allows the initial conditions to be manually established and changed. Tsunami propagation models such as SWAN (Mader, 1988, 2004), TUNAMI-N2 (Imamura, 2006) and HyFlux2 (Franchello, 2008) are included in the interface to verify and compare the hydrodynamic theories (Fig. 12). The included models solve the two dimensional shallow water equations numerically. SWAN and TUNAMI-N2 use finite difference method. HyFlux2 uses finite volume method.
The models have also been implemented widely by different researchers to simulate tsunami propagations and wave heights in Pacific, Atlantic, and Indian Oceans, with zoom in at particular areas of Caribbean, Japanese, Russian, South China, Mediterrenean seas and Gulf of Cadiz (Yalciner et al., 2000, 2001, 2002; Baptista et al., 2003; Zahibo et al.,2003; Yalciner, 2004; Annunziato, 2007; Dao and Tkalich, 2007; Yolsal et al., 2007; Franchello ,2008; Franchello and Krausmann, 2008; Kaabouben et al., 2008; Annunziato et al., 2009; Dao, et al., 2009; Franchello, 2010; Yolsal and Taymaz, 2010; Cruz et al., 2011; Ulutas, 2011). Although the SWAN (Mader, 1988) model was adapted to the TEWS, which is a part of GDACS, all included models might be used manually in order to predict tsunami arrival times and maximum heights. The program interface allows the establishment and the change of SWAN, TUNAMI-N2 and HyFlux2 models. The initial condition window contains epicenter details, fault parameters, time and bathymetry features, boundaries of calculation area, graphic and numerical code options and case identification. It is also possible to change the form of the fault and its shape. The program can work in manual mode or in automatic mode. Another software application called Tsunami Analysis Tool (TAT) developed by Annunziato (2007) visualizes tsunami travel time and tsunami propagation by using the calculated simulations inserted to the program interface. TAT allows a comparison of the calculated value with the available sea level measurements downloaded from IOC and NOAA web sources.

In this study, the above mentioned models and source parameters of the earthquake were used to simulate the Mentawai Tsunami. Based on the initial parameters, the displacement of seafloor is determined from a linear elastic dislocation theory (Okada, 1985) (Fig. 13). In Fig. 13, red indicates uplift, while blue indicates subsidence. Two series of calculations have been performed with the various codes: the first one with cell size $1 \mathrm{~min}$, covering an area from $13.98^{\circ} \mathrm{S}$ to $7.01^{\circ} \mathrm{N}$ latitude and from $89.61^{\circ} \mathrm{E}$ to $110.61^{\circ} \mathrm{E}$ in order to compare far distant sea level measurements as the DART 56001 , located at $-13.96^{\circ} \mathrm{S}$ and $110.004^{\circ} \mathrm{E}$. The second one, with cell size $0.25 \mathrm{~min}$, covering from $0.70^{\circ} \mathrm{N}$ to $6.70^{\circ} \mathrm{S}$ latitude and $96.3^{\circ} \mathrm{E}$ to $105.0^{\circ} \mathrm{E}$, in order to have a better definition in the mostly affected area. All the calculations used resampled data originated from the SRTM30+ bathymetry data (Becker, et al., 2009). The maps of maximum tsunami heights performed using a $0.25 \mathrm{~min}$ cell size for SWAN, HyFlux2, and TUNAMI-N2 models are shown in Figs. 14, 15 and 16, respectively. The figures show that highest waves are estimated perpendicular to the strike of the fault. The highest estimated wave heights are 8.0, 5.9 and $3.8 \mathrm{~m}$ for TUNAMI-N2, SWAN and HyFlux2 codes, respectively. The heights in this study are relatively higher than the results of Ulutas (2011) for TUNAMI-N2 and SWAN models for the same region. The higher wave heights, when comparing to Ulutas (2011), are due to the use of the parameters of GCMT solution, higher average slip, more detailed 
Table 5. Epicentral location of earthquake, earthquake parameters and GCMT solution used in this study.

\begin{tabular}{ccccccccccc}
\hline $\begin{array}{c}* \mathrm{M}_{0} \\
(\mathrm{dyn} \mathrm{cm})\end{array}$ & $\begin{array}{c}{ }^{*} \text { Lat } \\
\left({ }^{0}\right)\end{array}$ & $\begin{array}{c}* \text { Lon } \\
\left({ }^{0}\right)\end{array}$ & $\begin{array}{c}* \text { Depth } \\
(\mathrm{km})\end{array}$ & $\begin{array}{c}* \text { Strike } \\
\left({ }^{0}\right)\end{array}$ & $\begin{array}{c}{ }^{*} \text { Dip } \\
\left({ }^{0}\right)\end{array}$ & $\begin{array}{c}* \text { Rake } \\
\left({ }^{0}\right)\end{array}$ & $\begin{array}{c}* * \mathrm{D} \\
(\mathrm{m})\end{array}$ & $\begin{array}{c}* * * \text { Length } \\
(\mathrm{km})\end{array}$ & $\begin{array}{c}* * * * \text { Width } \\
(\mathrm{km})\end{array}$ \\
\hline $6.6 \times 10^{* * 27}$ & $3.464 \mathrm{~S}$ & $100.084 \mathrm{E}$ & 20.6 & 319 & 7 & 98 & 4.76 & 112 & 31 \\
\hline
\end{tabular}

*USGS(2011), ${ }^{* *}$ Equation (1) *** Equation (1) **** Equation (2)

Table 6. Maximum heights in meters calculated from different models in some locations.

\begin{tabular}{|c|c|c|c|c|c|c|c|c|}
\hline \multirow[b]{2}{*}{$\begin{array}{l}\text { Arrival Time } \\
(25.11 .2010)\end{array}$} & \multirow[b]{2}{*}{ Locatiom } & \multirow[b]{2}{*}{$\mathrm{EM}^{*}$} & \multicolumn{3}{|c|}{ Model (0.25 min grid) } & \multicolumn{3}{|c|}{ Model (1 min grid) } \\
\hline & & & SWAN & TUNAMI-N2 & HyFLUX & SWAN & TUNAMI-N2 & HyFLUX \\
\hline $14: 50$ & Tiop & & 5.3 & 4.3 & $3.8+$ & 2.9 & 2.7 & 1.4 \\
\hline $14: 54$ & Bulasat & 3.0 & 4.2 & 3.9 & 3.1 & 2.6 & & 1.4 \\
\hline $14: 52$ & Beleratsok & & 3.3 & 3.1 & 2.1 & 1.9 & 2.4 & 1.0 \\
\hline $14: 54$ & Sabeugukgung & 3.0 & 2.7 & 2.0 & 2.2 & 2.0 & 1.6 & \\
\hline $14: 52$ & Seai & & 1.7 & 1.2 & 0.9 & & & \\
\hline $14: 52$ & Buriai & & 1.6 & 1.7 & 0.6 & 1.0 & & 0.3 \\
\hline $15: 32$ & Ipun & & 1.3 & & 0.6 & & & \\
\hline
\end{tabular}

* Eyewitness measurement (EM), (NGDC, 2011)

bathymetry and different grid calculations. It should be noted that the highest estimated wave height is obtained with the TUNAMI-N2 code in a location very close to the epicenter, i.e. $8.0 \mathrm{~m}$, which does not correspond to any populated place in our database. The list of some locations with the wave travel times and the wave heights are displayed in Table 6. The highest waves ranging from $1.4 \mathrm{~m}$ to $5.3 \mathrm{~m}$ are predicted from the models in Tiop and Bulasat villages. These differences are due to the use of different models and different grid calculations. The use of a more refined grid allows predicting higher wave heights because the points become more and more representative of the real depth. The tsunami arrives at Tiop and Bulasat about 8 and 12 min after the earthquake's origin time, respectively. The values reported in the NGDC (National Geophysical Data Center) database for Bulasat is $3.0 \mathrm{~m}$ (NGDC, 2011) and classified as eyewitness reported data but field survey analysis show that the observed tsunami heights are from 6-9 $\mathrm{m}$ around the Bulasat village (Koresawa, 2010).

The instrumental records of the Mentawai tsunami were also used for comparing the results of the numerical simulations. The buoy system arrays provide more tsunami measurements for future events, expanding the library of well-constrained propagation scenarios for model verification (Synolakis et al., 2008). Three buoys gave acceptable readings in that region. One of them is TS10 (lat/lon: $2.789167^{\circ} \mathrm{S} / 98.92194^{\circ} \mathrm{E}$ ), which is an an experimental GPS device installed in the frame of the German Indonesian Tsunami Early Warning System (GITEWS), an- other is TNBL (lat/lon.: $0.59^{\circ} \mathrm{S} / 98.5^{\circ} \mathrm{E}$ ). TNBL (Tanah Bala) is run by Badan Koordinasi Survei dan Pemetaan within the framework of UNESCO/IOC available from the web site (http://www.ioc-sealevelmonitoring.org), and the last is DART 56001 developed by PMEL (Pacific Marine Environmental Labaratory) available from the web site (http:// www.ndbc.noaa.gov/dart.shtml). The locations of the buoys are presented in Fig. 13. The time series of tsunami heights from the three models at the location of TS10, TNBL and DART 56001 are shown in Figs. 17, 18 and 19, respectively. The computed simulations of SWAN, TUNAMI-N2 and HyFlux 2 models are compared with these buoy readings for the 0.25 min grid size calculations.

For the TS10 sensor, the numerical models tend to give estimations that are very close to the measured data. The periods of SWAN, TUNAMI-N2 and HyFlux2 are almost identical for the first peak of the wave. The SWAN and HyFlux2 show identical periodic waves and appear to be similar for the second and third wave trains. Although the time series of the waves are slightly delayed in TUNAMI-N2, the wave heights are higher those that of SWAN and HyFlux2. The maximum value of the first peak is about $15 \mathrm{~cm}$ and the estimated value is about $10 \mathrm{~cm}$. However, it should be considered that this sensor contains a rather large oscillation even before the event, in the order of $4 \mathrm{~cm}$, which is therefore influencing also the maxima during the tsunami. The tidal gauge TNBL readings and results of numerical models are compared in Fig. 18. The wave periods and heights of the models are in good agreement with the observed data, except for the value 

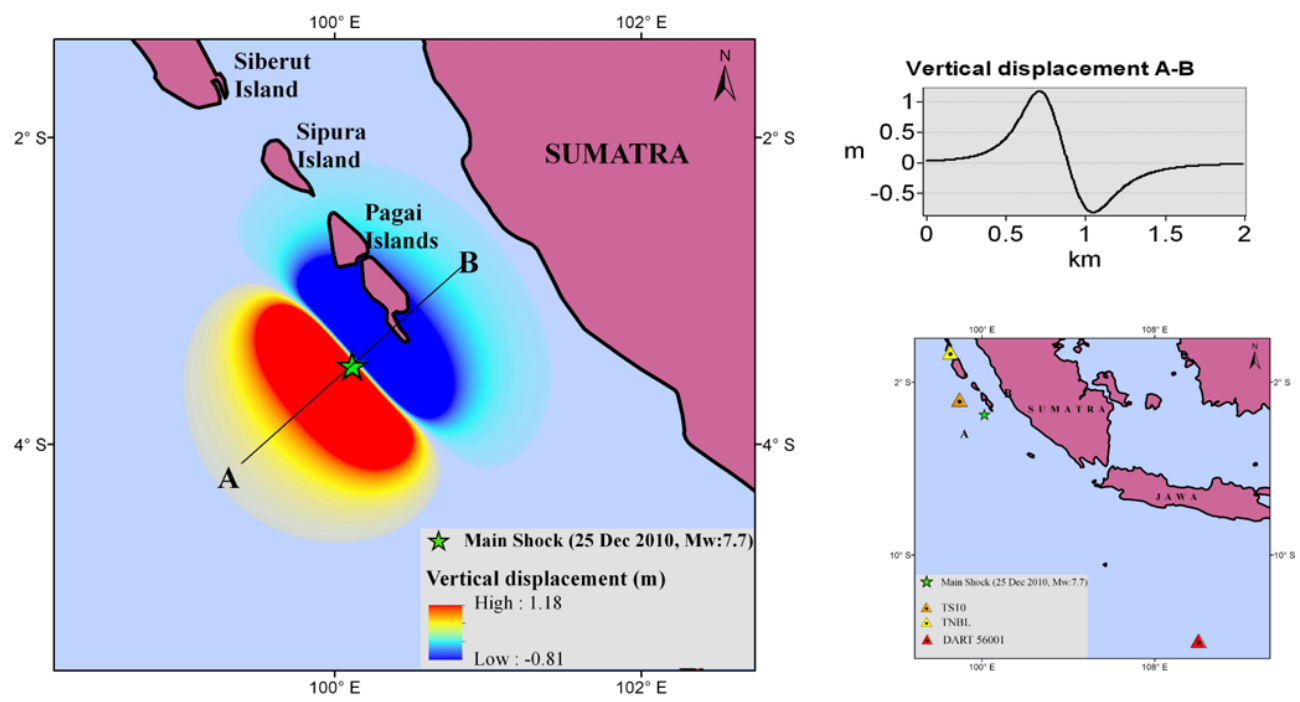

Fig. 13. Vertical dislocation of the sea floor, (b) Cross section of $A B$, (c) Location of the buoys.

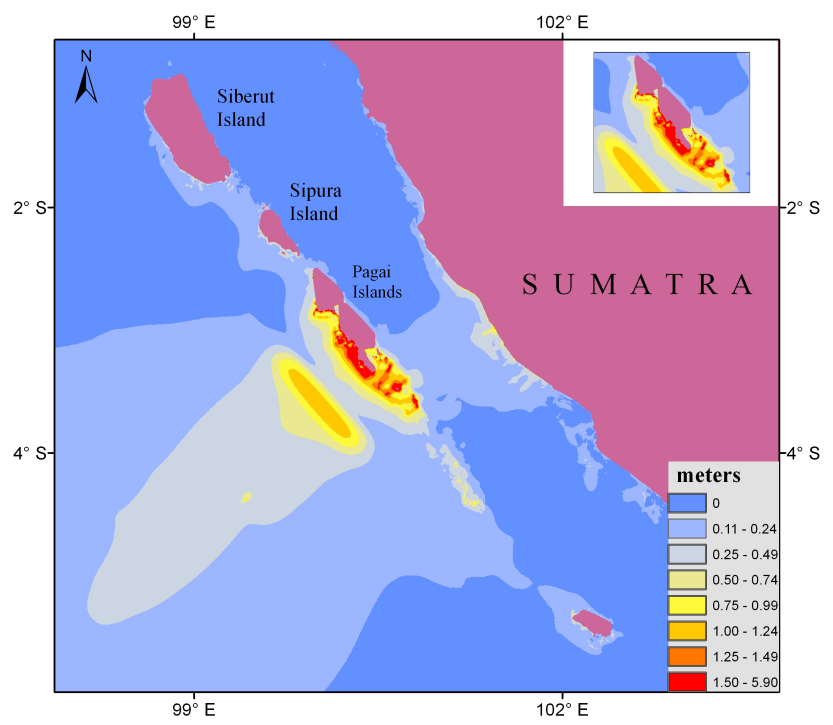

Fig. 14. Maximum computed heights from SWAN model with a cell size of $0.25 \mathrm{~min}$.

of first peak which is $30 \%$ lower. Although the wave periods of the models were almost in good agreement with the observed data, the wave heights were underestimated. The exact reproduction of the tidal gauges is not easy because the local conditions where the gauge is installed may strongly influence their response. In general these gauges are installed in ports and the detailed description of the port and its bathymetry would be necessary for a correct reproduction of the measured values. The DART 56001 recorded the tsunami waves, with peak-to-through amplitudes not exceeding $1 \mathrm{~cm}$. However, it can be seen that all the performed models almost fit well with the DART 56001 records (Fig. 19).

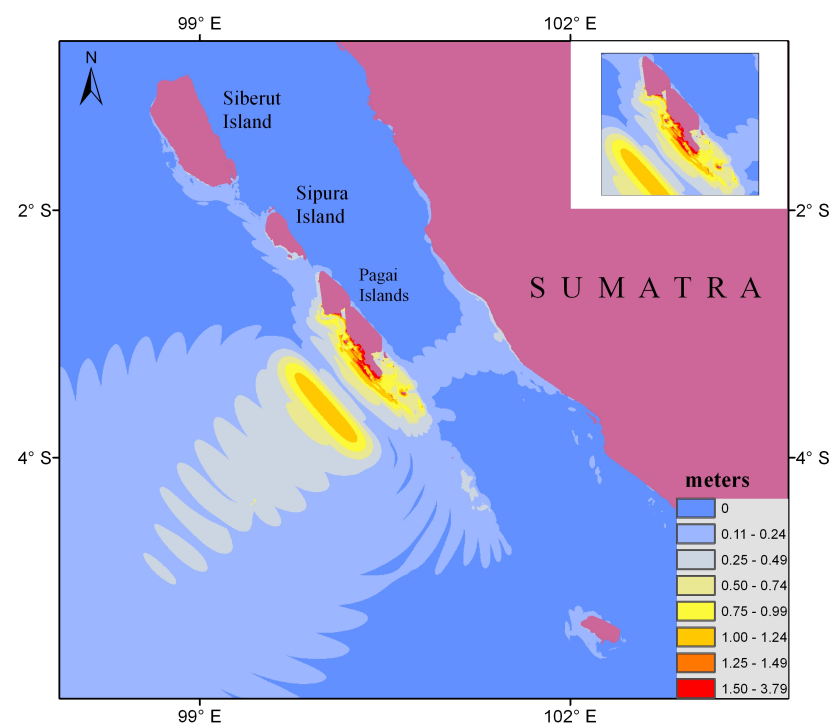

Fig. 15. Maximum computed heights from HyFlux2 model with a cell size of $0.25 \mathrm{~min}$.

\section{Discussion and conclusions}

This study presented the background and response of the Global Disasters Alerts and Coordination System (GDACS) to provide early estimates of the potential effect of tsunamis and issue alerts to the humanitarian community. The 25th October 2010 Kepulaunan Mentawai earthquake was chosen as the case study for the performance of the GDACS and post-event analysis of the earthquake. This web-based system is capable of releasing early warning information, including both tsunami arrival times and wave heights. Although it is difficult to release tsunami warnings in real 


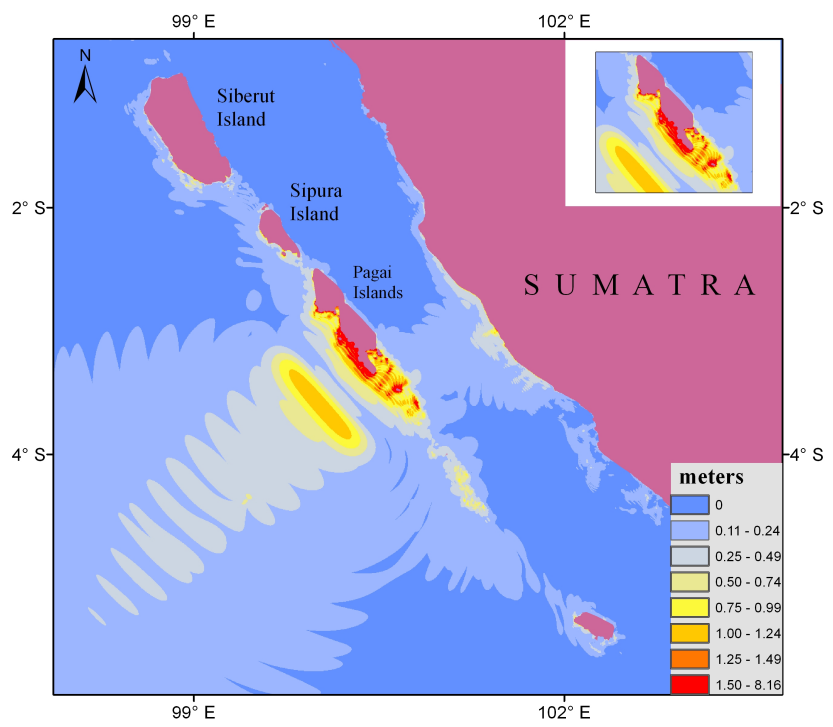

Fig. 16. Maximum computed heights from TUNAMI-N2 model with a cell size of $0.25 \mathrm{~min}$.

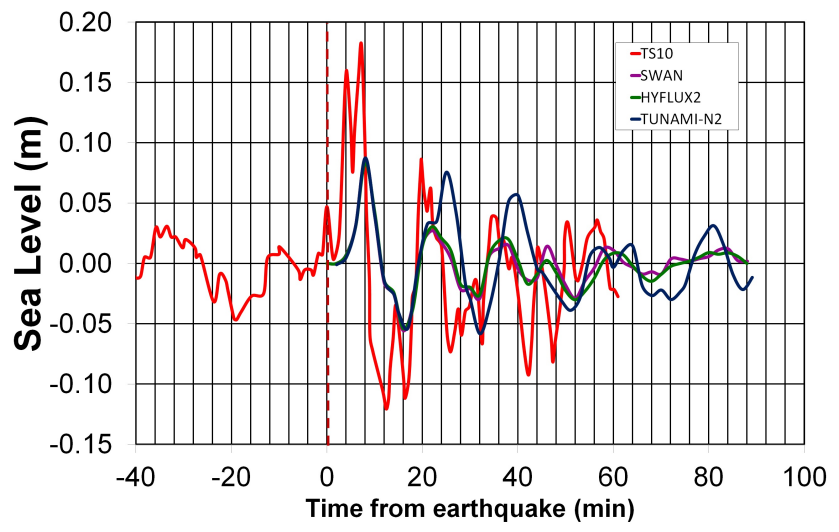

Fig. 17. Time series of sea level elevation from model forecasts for the earthquake compared to TS10.

time for near field regions, the GDACS reported a "green alert" to its users $11 \mathrm{~min}$ after the earthquake. The revised earthquake parameters pushed to the GDACS $2 \mathrm{~h}$ and $17 \mathrm{~min}$ after the event caused an "orange alert" to be issued. Unfortunately, shortly after occurrence of the earthquake, the detailed rupture mechanisms are not available for a simulation to get started. GDACS relies on pre-calculated scenarios selected using the earthquake estimations and in this case the latest verified estimate of the magnitude was issued $2 \mathrm{~h}$ after the earthquake. However, even with the latest verified magnitude by the seismological organizations, the estimated height $(1.5 \mathrm{~m})$ was much lower than the observed tsunami wave heights about $8-9 \mathrm{~m}$. The objective of the paper was therefore to understand the reason for this discrepancy. Although the preliminary estimates were successfully used in many other cases, such as the 2009 Samoa tsunami, the

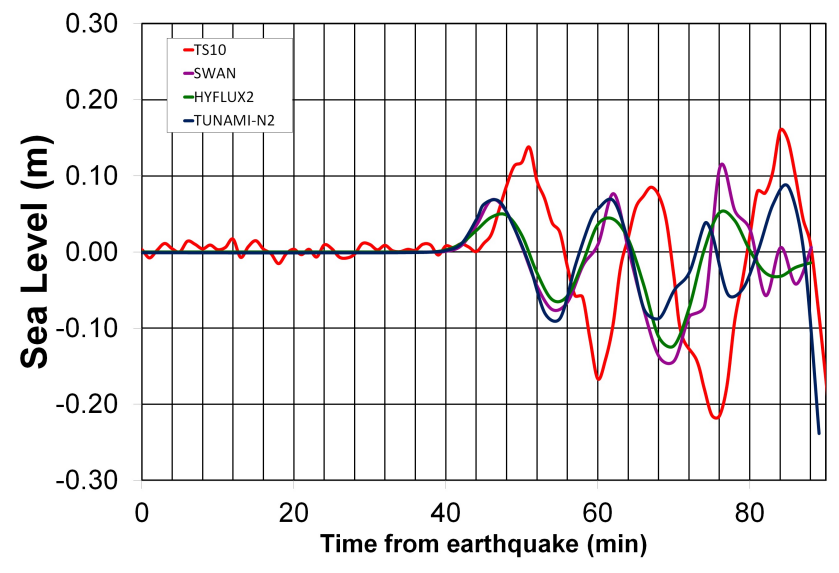

Fig. 18. Time series of sea level elevation from model forecasts for the earthquake compared to TNBL.

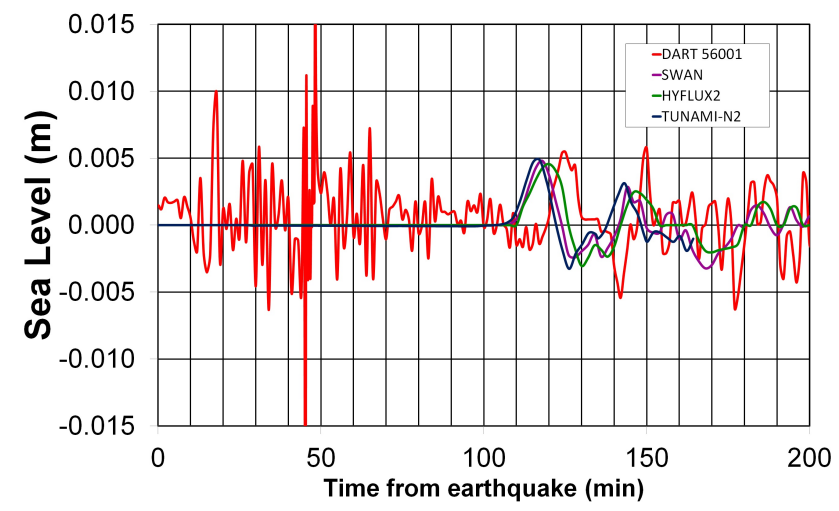

Fig. 19. Time series of sea level elevation from model forecasts for the earthquake compared to DART 56001.

2010 Chile tsunami and the 2011 Japan tsunami (GDACS, 2009, 2010a and 2011), the impact of the tsunami was not calculated correctly in this study event without considering the source mechanism solutions and an increased amount of slip during the rupture. After employing the USGS (2010b) source model and assumed fault parameters, the maximum heights predicted were $5.3 \mathrm{~m}$ (red alert) and $4.2 \mathrm{~m}$ in Tiop and Bulasat, respectively. These heights are higher than those predicted by pre-calculated models but are still consistently smaller than was reported by the field surveys (Koresawa, 2010). In some calculations we estimated about the same height as the field surveys, far from populated locations. The major reasons for the different estimations between the precalculated models and the post-event analyses could be attributed to considering the different fault mechanism and related initial deformation and to the too coarse bathymetry used for the pre-calculated scenarios. In particular, the value of the average slip was too low in connection with the assumption of uniform rupture area for the initial water surface deformation giving rise to the tsunami. In this study, 
the amount of slip motion was calculated using the equations of seismic moment (Aki, 1966) by using the scalar moment, rigidity, fault length and fault width. The average slip parameter was calculated as $4.76 \mathrm{~m}$ according to the seismic moment of the earthquake. The calculated average slip for this earthquake gives reasonable tsunami results when the GCMT fault mechanism parameters are used. The average slip is larger than the value that is used by GDACS automatic calculations. The reason for the larger tsunami run-ups was also accounted for by some authors who propose that this earthquake ruptured narrow margins up-dip of great underthrusting fault with total slip of $2-4 \mathrm{~m}$ over an $\sim 100 \mathrm{~km}$ long source region (Lay et al., 2011a, b) $\sim \mu$. The detailed post-event analysis (Newman et al., 2011) identified the slow propagating nature of this earthquake: the reduced rupture velocity could have been caused by regional reductions of the crustal rigidity along the shallow trench and the smaller crustal rigidity could have contributed to an increased initial slip, causing the 5-9 m local tsunami runup. The local different variable rigidity has not been accounted for in this study; rather, a uniform increase of the initial height has been accounted for and allowed to improve the results of the calculations. The consequences of the above assumptions might be an increase of the initial slip, which then resulted in a better agreement with all the measured data. We believe that the implications of the post-event study in light of the GDACS system's assessment of the earthquake will contribute to improve the approach for the pre-defined scenario database in the region. A better understanding of the active tectonics and rupture process in the region is important for evaluating the possible consequences of the future tsunamis for risk mitigation. In addition, the strong relation between bathymetry cell size and maximum estimated height suggest that the future version of the scenario database, in preparation at JRC, needs to be performed with greater detail close to the coast. Indeed, this is the way the new tsunami online calculation system and the corresponding new version of the scenario database will be developed. More refined calculations will be performed in locations where the coarse calculations evaluate higher water heights. A dedicated report to describe the new method is in preparation at JRC.

Acknowledgements. The authors would like to thank Mr. Joern Lauterjung and Alexander Rudloff for having provided the data related to the GITEWS GPS buoy, and Brian Doherty for the internal review of the paper. The authors are grateful for the financial support from Scientific and Technological Research Council of Turkey (TUBITAK) throughout the first and second author's post doctoral studies in European Commission Joint Reseach Center. They also would like to thank the editor and two anonymous reviewers for their constructive reviews of the manuscript.

Edited by: S. Tinti

Reviewed by: two anonymous referees

\section{References}

ADRC (Asian Disaster Reduction Center): Data Book on Asian Natural Disasters in the 20th Century, ADRC, Kobe, Japan, 2000 .

Aki, K.: Generation and propagation of $\mathrm{G}$ waves from the Niigata earthquake of June 14, 1964. Part 2. Estimation of earthquake moment, released energy and stress-strain drop from $G$ wave spectrum, Bull. Earth. Res. Inst., 44, 73-88, 1966.

Annunziato, A.: The Tsunam $\iota$ Assesment Modelling System by the Joint Research Center, Sci. Tsu. Hazards., 26, 70-92, 2007.

Annunziato, A., Matias L., Baptista, M. A., Carrilho F., and Ulutas, E.: Progresses in the establishment of the Portuguese Tsunami Warning System, 24th International Tsunami Sympossium, Book of Programme and Abstracts, Novosibirsk, 70, 2009.

Annunziato, A., Ulutas, E., and Titov, V. V.: Tsunami Model Study Using JRC-SWAN and NOAA-SIFT Forecast Methods, International Symposium on Historical Earthquakes and Conservation of Monuments and Sites in the Eastern Mediterranean Region 500th Anniversary Year of the 1509, Book of Proceedings, Istanbul, 131-141, 2009.

Baptista, M. A., Miranda, J. M., Chierici, F., and Zitellini, N.: New study of the 1755 earthquake source based on multi-channel seismic survey data and tsunami modeling, Nat. Hazards Earth Syst. Sci., 3, 333-340, doi:10.5194/nhess-3-333-2003, 2003.

BKSPN: Badan Koordinasi Survei dan Pemetaan Nasional, Tsunami vulnerability map of Indonesia, http: //www.bakornaspbp.go.id/html/tsunami.htm, last access: 31 May 2011, 2006.

Becker, J. J., Sandwell, D.T., Smith, W. H. F., Braud, J., Binder, B., Depner, J., Fabre, D., Factor, J., Ingalls, S., Kim, S.-H., Ladner, R., Marks, K., Nelson, S., Pharaoh, A., Trimmer, R., Rosenberg, J. Von., Wallace, G., and Weatherall, P.: Global Bathymetry and Elevation Data at 30 Arc Seconds Resolution: SRTM30_PLUS, Mar. Geod., 32, 4, 355-371, 2009.

Bird P.: An updated digital model of plate boundaries, Geochem. Geophys. Geosyst., 4, 1-52, 2003.

Bock, Y., Prawirodirdjo, L., Genrich, J. F., Stevens, C. W., and McCaffrey, R.: Crustal motion in Indonesia from Global Positioning System measurements, J. Geophys. Res., 108, 2367-2388, 2003.

Borrero, J. C., Sieh, K., Chlieh, M., and Synolakis, C. E.: Tsunami inundation modeling for western Sumatra, P. Natl. Acad. Sci. USA, 103, 19673-19677, doi:10.1073/pnas.0604069103, 2006.

Chamot-Rooke, N. and Le Pichon, X.: GPS determined eastward Sundaland motion with respect to Eurasia confirmed by earthquake slip vectors at Sunda and Philippine trenches, Earth Planet. Sci. Lett., 173, 439-455, 1999.

Cruz, A. M., Krausmann, E., and Franchello, G.: Analysis of tsunami impact scenarios at an oil refinery, Nat. Hazards, 58, 141-162, doi:10.1007/s11069-010-9655-x, 2011.

Dao, M. H. and Tkalich, P.: Tsunami propagation modelling a sensitivity study, Nat. Hazards Earth Syst. Sci., 7, 741-754, doi:10.5194/nhess-7-741-2007, 2007.

Dao, M. H., Tkalich, P., Chan, E. S., and Megawati, K.: Tsunami propagation scenarios in the South China Sea, J. Asian Earth Sci., 36, 67-73, 2009.

De Groeve, T.: Global Disaster Alert and Coordination System: More Effective and Efficient Humanitarian Response, Proceedinngs of the 14th TIEMS Annual Conference, 324-334, Trogir, Croatia, 2007. 
De Groeve, T., Vernaccini, L., and Annunziato, A.: Modelling Disaster Impact for the Global Disaster Alert and Coordination System, Proceedings of the 3rd International ISCRAM Conference, May 2006, Newark, NJ (USA), 409-417, 2006.

De Groeve, T., Peter, T., Annunziato, A., and Vernaccini, L.: Global Disaster Alert and Coordination System, http://www.gdacs.org/ documents/2009_GDACS_overview.pdf, 2009.

Dominey-Howes, D.: Documentary and geological records of tsunamis in the Aegean Sea region Greece and their potential value to risk assessment and disaster management, Nat. Hazards, 25, 195-224, 2002.

Dominey-Howes, D., Cummins, P., and Burbridge, D.: Historic records of teletsunami in the Indian Ocean and insights from numerical modeling, Nat. Hazards, 42, 1-17, 2007.

ETOPO2: Global Gridded 2-minute Database, National Geophysical Data Center, National Oceanic and Atmospheric Administration, U.S. Dept. of Commerc, http://www.ngdc.noaa.gov/mgg/ global/etopo2.html, 2006.

EMM: European Media Monitoring, http://emm.jrc.it/NewsBrief/ search/en/advanced.html, 2010.

Fitch, T. J.: Plate convergence, transcurrent faults and internal deformation adjacent to southeast Asia and the western Pacific, J. Geophys. Res., 77, 4432-4460, 1972.

Franchello, G.: Modelling Shallow Water Flows by a High Resolution Riemann Solver, JRC Scientific and Technical Reports, EUR 23307 EN, 2008.

Franchello, G. and Krausmann, E.: HyFlux2: a numerical model for the impact assessment of severe inundation scenario to chemical facilities and downstream environment, JRC Scientific and Technical Reports, EUR 23354 EN, 2008.

Franchello, G.: Shoreline tracking and implicit source terms for a well balanced inundation model, Int. J. Num. Meth. Fluids, 63, 1123-1146, 2010.

GDACS: Global Disasters Alerts and Coordination System, Red Tsunami and Earthquake alert in Samoa WS, wave heights and arrival time, http://www.gdacs.org/reports.asp?eventType=EQ\} \&ID=66525 \\&system, last accessed: 26 October 2011, 2009.

GDACS: Global Disasters Alerts and Coordination System, Orange Tsunami and Earthquake alert in Indonesia, wave heights and arrival time, http://w3.gdacs.org/reports.asp?ID=96318, last access: 11 December 2011, 2010b.

GDACS: Global Disasters Alerts and Coordination System, Red Tsunami and Earthquake alert in Chile, wave heights and arrival time, http://www.gdacs.org/reports.asp?eventType=EQ $\backslash$ \&ID=66525 \\&system, last access: 26 October 2011, 2010a.

GDACS: Global Disasters Alerts and Coordination System, Red Tsunami and Earthquake alert in Japan, wave heights and arrival time, http://ec.europa.eu/dgs/jrc/index.cfm?id=1410 \\&obj_ $\mathrm{id}=13030 \backslash \& \mathrm{dt}_{\mathrm{d}}$ code $=\mathrm{NWS}\{\backslash \&\}$ lang=en, accessed on 11 December 2011, 2011.

Greenslade, D. J. M. and Titov, V. V.: Comparison Study of Two Numerical Tsunami Forecasting Systems, Pure Appl. Geophys., 165, 1991-2001, 2008.

Hanks, T. C. and Kanamori, H.: A moment magnitude scale, J. Geophys. Res., 84, 2348-2350, 1979.

Imamura, F., Yalciner, A. C., and Ozyurt, G.: Tsunami Modelling Manual, available from: http://ioc3.unesco.org/TsunamiTeacher/ data/Resource/PDF/PubPriv_109_TMM.pdf, last access: 25 Novamber 2011, 2006.
JRC: Joint Research Center, Europa Technologies, available from: http://www.gdacs.org, 2010.

Kaabouben, F., Brahim, A. I., Toto, E., Baptista, M. A., and Miranda, J. M., Soares, P., and Luis, J. F.: On the focal mechanism of the 26.05.1975 North Atlantic event contribution from tsunami modeling, J. Seismol., 12, 575-583, doi:10.1007/s10950-0089110-6, 2008.

Koresawa, A.: Field Survey of Tsunami Stricken Areas in the Mentawai Islands: focusing on policy aspects, ICA-JST Indonesia Multi-disciplinary Hazard Reduction from Earthquakes and Volcanoes in Indonesia, 5th-10th November, Indonesia, http://www.adrc.asia/adrcreport_e/archives/2010/11/ 26100319.html, 2010.

Lay, T., Ammon, C. J., Kanamori, H., Yamazaki, Y., Cheung, K. F., and Hutko, A. R.: The 25 October 2010 Mentawai tsunami earthquake (Mw 7.8) and the tsunami hazard presented by shallow megathrust ruptures, Geophy. Res. Lett., 38, L06302, doi:10.1029/2010GL046552, 2011a.

Lay, T., Ammon, C. J., Kanamori, H., Xue, L., and Kim, J.: Possible large near trench slip during the great 2011 Tohoku $\left(\mathbf{M}_{w} 9.0\right)$ earthquake, Earth Planets Space, 687-692, 2011 b.

Mader, C.: Numerical Modeling of water waves, University of California Press, Berkeley, California, p.206, 1988.

Mader C.: Numerical modeling of water waves, CRC Press - ISBN 0-8493-2311-8, 2004.

Marfai, M. A., King, L., Singh, L. P., Mardiatno, D., Sartohadi., J., Hadmoko and Dewi, A.: Natural Hazards in Central Java Province, Indonesia: an overview, Environ Geol., 56, 335-351, 2008.

McCaffrey, R.: The tectonic framework of the Sumatran subduction zone, Annu. Rev. Earth Pl. Sc., 37, 345-366, 2009.

Natawidjaja, D., Sieh, K., Chlieh, M., Galetzka, J., Suwargadi, B., Cheng, H., Edwards, R. L., Avouac, J. P., and Ward, S.: Source parameters of the great Sumatran megathrust earthquakes of 1797 and 1833 inferred from coral microatolls, J. Geophy. Res., 111, B06403, doi:10.1029/2005JB004025, 2006.

NGDC (National Geophysical Data Center): Tsunami Event Search-sorted by date, country, http://www.ngdc.noaa.gov, accessed on 25 November 2011, 2011.

Newman, A. V., Hayes, G., Wei, Y., and Convers, J.: The 25 October 2010 Mentawai tsunami earthquake, from real-time discriminants, finite-fault rupture, and tsunami excitation, Geophy. Res. Lett., 38, L05302, doi:10.1029/2010GL046498, 2011.

OCHA (United Nations Office for the Coordination of $\mathrm{Hu}-$ manitarian Affairs): http://ochaonline.un.org/indonesia/ SituationReports/DailyUpdate/tabid/7277/language/en-US/ Default.aspx, 2011.

Okada, Y.: Surface deformation due to shear and tensile faults in a half-space, Bull. Seismol. Soc. Am., 75, 1135-1154, 1985.

ReliefWeb: Tsunami - Mentawai Islands - Sibigau Islands and South Pagai Coast - as of 01 Nov Fri, http://reliefweb.int/node/ 18540, last access 11 December 2011, 2010.

Sieh, K.: The Sunda Megathrust- Past, Present and Future, J. Earthquake Tsunami, 1, 1, 1-19, 2007.

Sutikno, S., Earthquake disaster of Yogyakarta and Central Java, and disaster reduction, Indonesia, Forum Geogr., 21, 1, 1-16, 2007.

Synolakis, C. E., Bernard, E. N., Titov, V. V., Kanoglu, U., and Gonzalez, F. I.: Validation and Verification of Tsunami Numeri- 
cal Models, Pure Appl. Geophys., 165, 2197-2228, 2008.

Titov, V. V., Gonza' lez, F. I., BEernard, E. N., Eble, M. C., Modfjeld, H. O., Newman, J. C., and Venturato, A. J.: Real-time tsunami forecasting: Challenges and solutions, Nat. Hazards, 35, 41-58, 2005.

Ulutas, E.: Tsunami simulation of the October 25, 2010, South Pagai Island, Sumatra earthquake, Int. J. Phys. Sci, 6, 459-475, 2011.

UNESCO/IOC-NOAA ITIC: International Post- Tsunami Survey for the 25 October 2010 Mentawai, Indonesia Tsunami, International Tsunami Survey Team-Mentawai (ITST-Mentawai), 2010.

USGS, U.S. Geological Survey: Magnitude 7.7 - Kepulaunan Mentawai Region, Indonesisa, Tectonic Summary, available from: http://earthquake.usgs.gov/earthquakes/recenteqsww/ Quakes/usa00043nx.php\#maps last access: 25 November 2011, 2010a.

USGS, U.S. Geological Survey: Global CMT Project Moment Tensor Solution, available from: http://earthquake. usgs.gov/earthquakes/eqinthenews/2010/usa00043nx/

neic_a00043nx_gcmt.php, last access: 25 November 2011, 2010b.

USGS, U.S. Geological Survey: Earthquake Hazards Program, Earthquake details, Magnitude 7.7-Kepulaunan Mentawai Region, Indonesia, http://earthquake.usgs.gov/earthquakes/ recenteqsww/Quakes/usa00043nx.php last access: on 25 November 2011, 2010c.

Utsu, T., Shima, E., Yoshii, T., and Yamashina, K.: Encylopedia of earthquakes, 2nd ed. Tokyo: Asakura, 2001 (in Japanese).

Ward, S. N.: Tsunamis, The Encyclopedia of Physical Science and Technology, edited by: Meyers, R. A., Academic Press, 17, 175191, 2002.
Yalciner, A. C., Altinok, Y., and Synolakis, C. E.: Tsunami waves in Izmit Bay after the Kocaeli Earthquake, Earthquake Engineering Research Institute, USA (Chapter 13), 2000.

Yalciner, A. C., Synolakis, A. C., Alpar, B., Borrero, J., Altinok, Y., Imamura, F., Tinti, S., Ersoy, S., Kuran, U., Pamukcu, S., and Kanoglu, U.: Field surveys and modeling 1999 Izmit tsunami, in: International Tsunami Symposium ITS 2001, Session 4, Paper 4-6, Seattle, 7-9 August 2001, 557-563, 2001.

Yalciner, A. C., Alpar, B., Altinok, Y., Ozbay, I., and Imamura, F.: Tsunamis in the Sea of Marmara: historical documents for the past, models for future, Special Issue Mar. Geol., 190, 445-463, 2002.

Yalciner, A., Pelinovsky, E., Talipova, T., Kurkin, A., Kozelkov, A., and Zaitsev, A.: Tsunamis in the Black Sea: comparison of the historical, instrumental, and numerical data. J. Geophys. Res., 109, C12023, doi:10.1029/2003JC002113, 2004.

Yolsal, S., Taymaz, T., and Yalciner, A. C.: Understanding tsunamis, potential source regions and tsunami-prone mechanisms in the Eastern Mediterranean, Geol. Soc., London, Special Publ., 291, 201-230, 2007.

Yolsal, S. and Taymaz, T.: Sensitivitiy analysis on relations between earthquake rupture parameters and far-field tsunami waves: Case studies in the Eastern Mediterranean region, Turkish J. Earth Sci., 19, 313-349, doi:10.3906/yer-0902-8,2010.

Zahibo, N., Pelinovsky, E., Yalciner, A. C., Kurkin, A., Kozelkov, A., and Zaitsev, A.: The 1867 Virgin Island tsunami: observations and modeling, Oceanol. Acta, 26, 609-621, 2003. 